This item was submitted to Loughborough's Research Repository by the author.

Items in Figshare are protected by copyright, with all rights reserved, unless otherwise indicated.

\title{
The role of structural breaks, nonlinearity and asymmetric adjustments in African bilateral real exchange rates
}

\section{PLEASE CITE THE PUBLISHED VERSION}

http://dx.doi.org/10.1016/j.iref.2016.05.004

\section{PUBLISHER}

(C) Elsevier

VERSION

AM (Accepted Manuscript)

\section{PUBLISHER STATEMENT}

This work is made available according to the conditions of the Creative Commons Attribution-NonCommercialNoDerivatives 4.0 International (CC BY-NC-ND 4.0) licence. Full details of this licence are available at: https://creativecommons.org/licenses/by-nc-nd/4.0/

\section{LICENCE}

CC BY-NC-ND 4.0

\section{REPOSITORY RECORD}

Ahmad, A.H., and Olalekan B. Aworinde. 2019. "The Role of Structural Breaks, Nonlinearity and Asymmetric Adjustments in African Bilateral Real Exchange Rates". figshare. https://hdl.handle.net/2134/21426. 


\title{
The Role of Structural Breaks, Nonlinearity and Asymmetric Adjustments in African Bilateral Real Exchange Rates
}

\author{
Ahmad Hassan Ahmad*† Olalekan Bashir Aworinde ${ }^{\ddagger}$
}

\begin{abstract}
This paper examines the validity of the purchasing power parity, PPP for six African countries of Botswana, Ghana, Kenya, Nigeria, South Africa and Tanzania using the countries' bilateral real exchange rates with their fifteen major trading partners for the period 19602011. It uses the Lagrangian multiplier, LM, which accommodates up to two endogenous structural breaks in addition to conventional unit root tests. The paper also uses the threshold cointegration tests to explore nonlinearity and asymmetric adjustments of the series. Results from the LM unit root tests indicate that the exchange rates of Botswana, Ghana, Kenya and Nigeria relative to their major trading partners are stationary. The results from the threshold cointegration suggest that there is a long-run relationship between the series and that the adjustments are asymmetric. Appreciation is faster than depreciation in most of the countries. This is consistent with suggestions that countries are intolerant of depreciation.
\end{abstract}

Key Words: PPP, Bilateral exchange rates, LM test, Structural breaks, Asymmetric Cointegration, African countries

JEL Classification: F30, F31, C22

\footnotetext{
*School of Business \& Economics, Loughbrough University, Leicestershire, LE11 3TU, United Kingdom, A.H.Ahmad@lboro.ac.uk

${ }^{\dagger}$ We are very grateful to the editor and acknowledge the anonymous reviewer's useful and constructive comments.

${ }^{\ddagger}$ Department of Economics, University of Bath, Bath, BA2 7AY \& College of Social and Management Sciences, Tai Solarin University of Education, Ijebu-Ode, Nigeria.
} 


\section{Introduction}

The purchasing power parity, PPP, hypothesis has been a major topical issue over the years and a huge amount of empirical work has been done in the area for both developed and developing countries. The major reason for this interest is because of an important implication it has on trade and capital movements. Over the years, the evidences presented by the empirical literature are generally mixed, which were largely attributed to differences in methodology and the sample period covered by these studies. This is because the sample period may contain structural breaks that could be due to policy regime shifts and structural shocks, which were largely overlooked.

The empirical literature on the PPP can be classified into four groups based on the methodology used. The first group is the literature that used univariate unit root tests to examine the PPP hypothesis, but arrived at different conclusions. For example, Grilli and Kaminsky (1991) reported evidence that supports the validity of the PPP whereas Doganlar, et al. (2009) and Flynn and Boucher (1993) did not find evidence that supports the PPP. Furthermore, results from sub-sample of the data studied are also at variance with one another. For example, Grilli and Kaminsky (1991) find that the PPP holds for the entire sample period, but not for the sub-samples of floating and fixed regime periods while Odedokun (2000) reports that the PPP holds in 17 out of 35 countries studied.

The second group consists of those who applied panel unit root techniques. Frankel and Rose (1996), Papell and Theodoridis (1998), O'Connell, (1998), Fleissig and Strauss (2000) and Taylor (2002) fall within this group. Their findings are generally supportive of the PPP hypothesis. The third one is a sub-set of the literature that used nonlinear unit root techniques. This includes Taylor et al. (2001), Chortareas, et al. (2002), Kilian and Taylor (2003), Sarno, et al. (2004) and Yilanci and Eris (2013). The results from this group have indicated that there is evidence of nonlinear mean 
reversion.

The fourth one includes those who have applied linear and nonlinear cointegration to investigate the PPP hypothesis. This literature looks into symmetric and asymmetric long run relationship between nominal exchange rate and the domestic and foreign price levels. Those that applied linear cointegration include Karfakis and Moschos (1989), Kim (1990), Mahdavi and Zhou (1994) and Kargbo (2006) and they found support for the PPP hypothesis. Enders and Dibooglu (2001), Enders and Chumrusphonlert (2004), Holmes and Wang (2006) and Karoglou and Morley (2012), on the other hand, have used asymmetric cointegration techniques to look into the relationship between nominal exchange rate and the domestic and foreign price levels. They have also found evidence that is supportive of the PPP hypothesis.

This study tests for the long-run PPP hypothesis in six African countries by analyzing their bilateral exchange rates relative to their trading partners ${ }^{1}$. These are Botswana, Ghana, Kenya, Nigeria, South Africa and Tanzania. These countries have undertaken reforms in the 1980s and the 1990s, from which trade and foreign exchange liberalization were part of. The main aim was to have their exchange rates as close as possible to their longrun equilibrium rates. Thus, making the countries good candidates for the analysis.

The major contribution of the paper is three folds. First, we examine the numeraire currency in validating the PPP condition by expressing the six African real exchange rates with their main trading partners. This approach is a departure from the existing literature, whch has used the exchange rates denominated in the US dollar. Instead, the paper uses the countries' bilateral real exchange rates based on the numeraire currency. Secondly, we examine the properties of the time series to identify the possibility of struc-

\footnotetext{
${ }^{1}$ The number of countries and the sample size are both determined by availability of data. This is discussed under the Data Section of the paper.
} 
tural breaks in the data using the LM test that allows up to two structural breaks. Third, the study used Threshold Cointegration Tests of Enders and Siklos (2001) to investigate nonlinearity and asymmetric adjustments of the series. This is important as identified by various authors that authorities try to influence the behaviour of their exchange rates. It was found by this literature that countries are generally intolerant to exchange rate depreciation and therefore, they use monetary policy as well as direct intervention in the foreign exchange markets to prevent their domestic currencies from depreciating or appreciating ${ }^{2}$. These actions can lead to both nonlinearity and asymmetric adjustments in the series. Overlooking them may have serious implication for conclusion on whether the PPP holds or not.

The rest of the paper is structured as follows. The next section outlines and explain the methodology used in the paper. Section 3 discusses the data as well as analyses the estimated results while Section 4 concludes.

\section{Methodology}

\subsection{The Unit Root Tests}

The LM test of Lee and Strazicich (2003), endogenously determines structural breaks in a series. It also addresses the problems of bias and spurious rejections which other tests are criticized of as shown in Lee and Strazicich (2003) that it is based on the LM principles. Furthermore, the tests correspond to Perron's (1989) exogenous structural break with a change in the level and the trend. Lee and Strazicich's (2003) model allows for two endogenous breaks both under the null and the alternative hypothesis ${ }^{3} .{ }^{4}$ The

\footnotetext{
${ }^{2}$ See Calvo and Reinhart (2002) for full discussions.

${ }^{3}$ The LM unit root tests statistics is given by: $\tau=t$-statistics for testing the null of a unit root $(\phi=0)$. To endogenously determine the location of two breaks $\left(\lambda_{j}=\frac{T_{B J}}{T}, j=1,2\right)$, the minimum LM unit root selects all plausible break points for the minimum statistic. See Lee and Strazicich (2003) for the details of the model.

${ }^{4}$ In addition, we also run conventional unit root tests: augmented Dickey Fuller, ADF and Phillips Perron, PP. These are standard tests found in the literature and hence, they
} 
test has been shown to perform well as compared to other data-dependent procedures that select the number of lagged augmented terms. Advantages of the two-break minimum LM unit root test can be summarized as follows. First, the break points are endogenously determined from the data. Second, the test is not subject to spurious rejections in the presence of a unit root with break(s). Third, when the alternative hypothesis is true and spurious rejections are absent, Lee and Strazicich (2003) demonstrate that the two-break minimum LM test has greater or comparable power to the Lumsdaine-Papell, LP, Test.

\subsection{Asymmetric Cointegration Tests}

To examine the long-run PPP and also explore the possibility of non-linearity as well as asymmetric adjustments in the series, the study uses the Enders and Siklos (2001) asymmetric cointegration methodology. Relationship between nominal exchange rates and domestic and foreign price levels can be expressed as:

$$
e_{t}=\beta_{0}+\beta_{1} p_{t}^{*}+\beta_{2} p_{t}+\varepsilon_{t}
$$

where $e_{t}$ is the logarithm of the bilateral exchange rates in the domestic currency; $p_{t}^{*}$ and $p_{t}$ represent the logarithm of foreign and domestic price levels, respectively, and $\varepsilon_{t}$ is the stochastic disturbance term. The model in equation (1) can be tested for a long-run relationship. After estimating the model, the obtained residuals series $\varepsilon_{t}$ are subjected to a unit root test that in form of:

$$
\Delta \varepsilon_{t}=\rho \varepsilon_{t-1}+v_{t}
$$

where $\varepsilon_{t}$ is the regression residuals from equation (1) and assumed to be purely white noise with a zero mean and a constant variance while $v_{t}$ is an independent and identically distributed disturbance with zero mean. If the are not discussed here. 
null $\rho=0$ can be rejected, then $\varepsilon_{t}$ is stationary. The model in equation (2) assumes a symmetric adjustment process and, therefore, change in $\varepsilon_{t}$ is $\rho \varepsilon_{t-1}$ regardless of whether $\varepsilon_{t-1}$ is positive or negative. But, if bilateral exchange rate and the price levels exhibit asymmetric adjustment behaviour, then the model in equation (2) is mis-specified. Enders and Siklos (2001) propose two test of asymmetries; a threshold autoregressive (TAR) and a momentum-threshold autoregressive (M-TAR) models. Following Enders and Siklos (2001) two different hypotheses can be tested. The TAR model is given as:

$$
\Delta \varepsilon_{t}=I_{t} \rho_{1} \varepsilon_{t-1}+\left(1-I_{t}\right) \rho_{2} \varepsilon_{t-1}+v_{t}
$$

where $I_{t}$ is the Heaviside indicator such that

$$
I_{t}=\left\{\begin{array}{lll}
1 & \text { if } & \varepsilon_{t-1} \geq \tau \\
0 & \text { if } & \varepsilon_{t-1}<\tau
\end{array}\right\}
$$

where $\tau$ is the value of the threshold and it is endogenously determined using the Chan (1993) technique. The method arranges the values of $\varepsilon_{t}$ and $\Delta \varepsilon_{t}$ for the TAR and the M-TAR models respectively in ascending order and excludes the smallest and the largest 15\%, making $\tau$ consistent estimate which yields the smallest residual sum of squares over the remaining $70 \%$.

The M-TAR model takes the following form:

$$
\Delta \varepsilon_{t}=M_{t} \rho_{1} \varepsilon_{t-1}+\left(1-M_{t}\right) \rho_{2} \varepsilon_{t-1}+v_{t}
$$

where $M_{t}$ is the Heaviside indicator function of the form

$$
M_{t}=\left\{\begin{array}{lll}
1 & \text { if } & \Delta \varepsilon_{t-1} \geq \tau \\
0 & \text { if } & \Delta \varepsilon_{t-1}<\tau
\end{array}\right\}
$$

The necessary condition for the stationarity of $\varepsilon_{t}$ is that $\rho_{1}<0, \rho_{2}<0$ and $\left(1+\rho_{1}\right)\left(1+\rho_{2}\right)<1 .^{5}$ If $\varepsilon_{t-1}$ is above the long-run equilibrium value, then adjustment is at the rate of $\rho_{1}$, but if $\varepsilon_{t-1}$ is below the long-run equilibrium value then adjustment is at the rate of $\rho_{2}$. However, adjustment is symmetric

\footnotetext{
${ }^{5}$ See Petrucelli and Woolford (1984) for full details.
} 
if $\rho_{1}=\rho_{2}$. Therefore, where the null hypothesis $H_{0}:\left(\rho_{1}=\rho_{2}\right)$ is rejected, then the TAR model can be used to capture the signs of the asymmetries. The M-TAR model is useful when the adjustment exhibits more momentum in one direction than the other. That is, the speed of adjustment depends on whether $\Delta \varepsilon_{t-1}$ is increasing or decreasing. If $\left|\rho_{1}\right|<\left|\rho_{2}\right|$, then increases in $\Delta \varepsilon_{t-1}$ may tend to persist, whereas decreases revert back to the threshold are done quickly.

Enders and Siklos (2001) proposed two sets of tests to test the null hypothesis $H_{0}: \rho_{1}=\rho_{2}$ in equation (5) for both the TAR and M-TAR models. The $F$-statistic does not follow the standard distribution, consequently, $\phi_{u}$ from the estimated TAR model is compared with $\phi_{u}^{*}$ for the M-TAR model provided in Enders and Siklos (2001). Since there is no presumption whether to use TAR or M-TAR model, the recommendation is to use the information criteria to determine the better model among the two. If the residuals in equations (3) and (5) are serially correlated, they are:

$$
\Delta \varepsilon_{t}=I_{t} \rho_{1} \varepsilon_{t-1}+\left(1-I_{t}\right) \rho_{2} \varepsilon_{t-1}+\sum_{i=1}^{p} \beta_{i} \Delta \varepsilon_{t-i}+v_{t}
$$

and

$$
\Delta \varepsilon_{t}=M_{t} \rho_{1} \varepsilon_{t-1}+\left(1-M_{t}\right) \rho_{2} \varepsilon_{t-1}+\sum_{i=1}^{p} \gamma_{i} \Delta \varepsilon_{t-i}+v_{t}
$$

Model in equation (7) represents the new TAR model while the one in equation (8) is the modified M-TAR model, respectively.

\section{Data and the Estimated Results}

\subsection{Data}

The data-set used in this analysis consists of annual series covering the period 1960 - 2011 for six Africa countries ${ }^{6}$. The countries covered are

\footnotetext{
${ }^{6}$ The sample period of $1960-2011$ was a limitation imposed by availability of data for the countries studied. However, the number of observations is adequate for time
} 
Botswana, Ghana, Kenya, Nigeria, South Africa and Tanzania along with their fifteen major trading partners. The bilateral real exchange rate is constructed from the bilateral nominal exchange rate, $e_{t}$, consumer price indices (foreign, $p_{t}^{*}$ and domestic, $p_{t}$ ), using $q_{t}=e_{t}+p_{t}^{*}-p_{t}$ (all in logs). The exchange rates are expressed in terms of the numeraire. The data are sourced from the World Bank Development Indicators database.

\subsection{The Unit Root Test Results}

\subsubsection{The ADF and the PP Tests}

In addition to the LM test discussed in Section 2 above, we also present and discuss the Augmented Dickey Fuller, ADF, and the Philips-Perron, PP, unit root tests have also been carried out. The results are reported in Tables 1a - 1f. The results for the ADF are reported in the left column of each of the tables while the right column reports those of the PP test. Results for Botswana's exchange rates relative to its trading partners in Table 1a indicate that the series are stationary with respect to eleven countries out of the fifteen countries investigated as suggested by the ADF test. However, the model with both a constant and a trend rejects the null of unit root in thirteen countries. Thus, implying evidence for the PPP in thirteen countries. Results in Table 1b show that Ghana's bilateral real exchange rates from both tests indicate fewer rejections of the null. The model with a constant only rejects the null with respect to Turkey, whereas the model with a constant and a trend reports evidence that supports the PPP with respect to Singapore and Turkey. The reason for the non-rejection of the null of unit root for Ghana's exchange rates with its partners might not be unconnected

series analysis as evident in literature. It is well established in the literature that annual observations of this magnitude or less are used for this type of analysis. Among those who used similar number of observations for such analysis include Bajo-Rubio et al (2004) who used annual series of 1964-2001, Mohammadi (2009) used annual data of 1960-2007, Onu (2014) analysed annual data of 1960-2010, Trachanas and Katrakilidis (2013a) and (2013b) that have used 1970-2010 and 1971-2009 annual series, respectively and Valadkhani and Nameni (2011) that used 1960-2008 annual series. 
to several currency crises experienced by the domestic currency, the Cedi, and the subsequent re-denomination of the exchange rate in January, 2008.

Results for Kenya from the two test show that the model with a constant reveals that the exchange rates are stationary with respect to eleven countries, while the model with a constant and a trend reports evidence that suggest the stationarity of the series with respect to eight trading countries. That is the tests failed to reject the null of unit root in these countries as evident in Table 1c. The Nigeria's bilateral real exchange rates did not exhibit mean reverting characteristics with all the countries as indicated by the model with a constant only by both tests. However, the model with both a constant and a trend reveal evidence supportive of the rejection of the null of unit root. The model indicates stationarity of the series with respect to eleven out of the fifteen countries examined.

Results for South Africa's bilateral exchange rates are contained in Table 1e. The model with a constant only suggests failure to reject the null of unit root in the series in respect of nine countries. That is the exchange rates are stationary in respect of these countries as indicated by both the ADF and the PP tests. The model with a constant and a trend reports similar number of rejections by the tests. It is clear from Table $1 \mathrm{f}$ that results from the model with a constant suggests that the Tanzania's bilateral real exchange rates fail to reject the null of unit root in favour of the alternative with respect to only one country by both tests. However, the model with both a constant and a time trend from the two tests reject the null of a unit root with respect to six countries.

It could be noted from the foregoing that the model with both a constant and a time trend reported more cases of failure to reject the null of unit root in the series and, in addition, the time trends have also been statistically significant. This could be suggestive for the presence of structural breaks. Secondly, countries that experienced currency crisis and other economic is- 
sues that subsequently led to the introduction of structural reforms have higher number of failure to reject of the null of unit root. For example, Ghana which recorded currency crisis and as a consequent introduced series of structural reforms has higher non rejections of the null than Botswana that has relatively stable economic and exchange rates.

\subsubsection{The LM Test with Structural Breaks}

The results from the LM Test that can account for up to two structural breaks are reported in Table 2. The results reported indicate evidence in favour of the PPP for Botswana's bilateral exchange rates relative to its eleven trading partners. The LM test with one structural break rejects the null of a unit root with respect to fourteen countries while one with two breaks rejected the null of a unit root for the Botswana's bilateral exchange rates with Israel, which was previously failed to reject by the one with one break. The results from the LM Test for In Ghana show that its bilateral exchange rate with all its trading partners exhibit mean reversion characteristics. This is in contrast to only two suggested by the PP Test; its exchange rates with Singapore and Turkey. Similarly, the LM Test that allowed for one breaks reports that the Kenya's bilateral exchange rates with nine of its trading partners considered are stationary. The results, therefore, suggest that the PPP holds for Kenya's bilateral exchange rate relative to nine of its major trading partners studied. However, the model that accounted for two structural breaks indicate that the exchange rates with all the fifteen countries in the sample are stationary.

Also, in addition to the ten countries where the PP test provides evidence supportive of the PPP for the Nigeria's real exchange rates, the LM with one structural break test rejects the null of unit root with three additional bilateral exchange rates. The test with two structural breaks found further evidence that supports the PPP hypothesis in all the fifteen bilateral real 
exchange rates considered. South Africa's results indicate that additional evidence supporting the validity of the PPP hypothesis was reported by both the LM Test with one and two structural breaks. Results from the test with two structural breaks have indicated that two additional bilateral exchange rates exhibit evidence in favour of the PPP. However, both the PP and the LM Tests show that South African bilateral exchange rates with the Netherlands are stationary. The LM Test with one break reports that Tanzania's real exchange rate show characteristics of mean reversion with nine countries in contrast to six reported by the PP. However, the LM Test with two structural breaks revealed that null of unit root was rejected for the country's real exchange rates with twelve countries.

The identified structural break dates by the LM Test were shown to have taken place mostly between the late seventies and nineties. The former was the period of severe external shocks experienced by the countries whereas the latter reflects institutional and structural reforms undertaken by the countries. The external shocks include oil price slumps of the 1990s and the resultant worsening in terms of trade as the countries are oil dependents, except Nigeria and Ghana for part of the sample period covered. Related here is commodity booms and bursts, particularly those of the 1970s, which constitute bulk of the countries' exports and whose revenues most of the countries depend on.

For example, in the case of Botswana, the 1970s was the period that marked the end of severe droughts the country experienced accompanied with a surge in foreign aid. An intensive diamond exploration and exports also started during this period, which helped the economy to record an annual growth rate of over $20 \%$. Botswana had also withdrawn from the Southern African Monetary Union in 1976 and subsequently introduced its own currency, the Pula, which replaced the South African Rand. The late 1970s and early 1980s saw the peak of the global diamonds' price to about 
$\$ 60,000$ per carat stone. This was known as the period of massive diamond price bubbles. It is evident from the identified break dates that these, among others, are responsible for the break dates.

In addition to the external factors discussed, internal domestic policies that seem to reflect the break dates identified for Ghana and Kenya are the economic reforms introduced in 1983 and early 1990s. Kenya introduced economic structural reforms in 1980s and a subsequent one in 1993. Both seem to have been identified by the LM Tests. Similarly, in response to economic crisis faced by the country, Nigeria has introduced series of economic reforms, which started with an austerity measure in 1982. This was followed by major reform programmes in 1986, 1994 and 2003. For South Africa, the additional break dates reflect the end of apartheid system in the early 1990s and economic reforms of the late 1990s and 2000s. Tanzania also implemented economic reforms in 1986 and a follow-up programme between 1996 and 1999.

\subsection{The Results from the Cointegration Tests}

\subsubsection{Symmetric Cointegration Tests}

Symmetric cointegration test procedure, where the lag length for each country is selected using the AIC was applied to the series. The results are reported in Table 3 from, which it is evident that the null of no cointegration was failed to be rejected for Botswana's bilateral exchange rate with nine of its major trading partners, while Ghana's and Kenya's real exchange rates, twelve for each. The results for Nigeria and South Africa show that the null of no cointegration of their exchange rate with their trading partners was failed to be rejected in respect to eight countries with the former and for 15 major trading partners in the case of the latter.

Non detection of cointegration among the series reported in Table 3 from the linear tests could be attributed to the presence of linearities and 
asymmetric adjustments of the series back to their fundamental subsequent to shocks. Moreover, these tests generally, have low power. Failure to reject the null of no cointegration by conventional tests of cointegration in the presence of nonlinearities and structural changes are well documented in the literature. For example, see among others Hansen and Seo (2002), Kejriwal and Perron (2008) and Balke and Fomby (1997). To address this, the paper uses the asymmetric cointegration of Enders and Siklos (2001) methodology explained in Section 2 and the estimated results are discussed in 3.3.2 below.

\subsubsection{Asymmetric Cointegration Tests}

The information criteria were used to determine whether the adjustment mechanism is best captured as a TAR or M-TAR process, while the LjungBox Q-statistic was used to determine whether the estimated model is free from serial correlation or otherwise. The results of the Enders and Siklos (2001) tests are reported in Table 4. Results for Botswana's real exchange rates relative to its fifteen trading partners indicate rejection of the null of no cointegration of the series with eight of its trading partners as compared to six reported from the symmetric cointegration tests. In addition, the speed of adjustment towards the PPP is significant based on Enders and Dibooglu (2001). The adjustment is symmetric in all the cases, except that of Norway as the null of $\rho_{1}=\rho_{2}$ was rejected at all the conventional level of

significance. Thus, indicates evidence for asymmetric adjustments back to equilibrium.

Results for threshold cointegration test for Ghana's real exchange rates show that the M-TAR model is favoured in most cases as the series with respect of 13 out of 15 countries. There is, therefore, strong evidence in favour of the PPP from the results. A major difference between these results and those reported in Table 3 for Ghana is that the evidence for cointegration and long-run PPP is substantially strengthened when asymmetries are ac- 
commodated. In addition, the long-run PPP holds in all the cases, where symmetric adjustment is also rejected, except only in the real exchange rates relative to Nigeria.

The results for Kenya's real exchange rates indicate that the null of no cointegration is rejected in relation to China, Egypt, France, India, the Netherlands, Pakistan and Spain at various levels of significance. Results for Nigeria's real exchange rates indicate that the M-TAR model is preferred to the TAR model, except in relation to Columbia and Ghana. Therefore, the results from the asymmetric tests provide evidence in support of the longrun PPP for Nigeria's exchange rates with its fourteen out of fifteen trading partners. Tests for the null of symmetric adjustments were also rejected in respect of all the series except for Ghana.

As evident from the results, test for threshold cointegration of South Africa's real exchange rate with its fifteen trading partners show that the AIC selects the M-TAR model as the preferred model in most cases. That is 10 out of 15 cases. It is also clear that the null of no cointegration was rejected with respect to South Africa's exchange rates relative to nine of its trading partners out of fifteen analyzed. A major difference between these results and those in Table 3 is that the evidence for cointegration and the long-run PPP is substantially strengthened when asymmetries in adjustments are taken care of. This is because the null of symmetric adjustment was rejected in all the cases except with respect to Switzerland at all the conventional level of significance. Threshold cointegration was found for Tanzania's bilateral exchange rates with ten of its trading partners, which are Bahrain, Japan, Kenya, Malaysia, South Africa, Saudi Arabia, Singapore, Switzerland, Turkey and the US.

In general, results from the threshold cointegration procedure suggest that the long-run relationship exists between the bilateral real exchange rates of the countries considered relative to most of their major trading partners 
analyzed $^{7}$. This, therefore, indicates that PPP holds for these countries for the period covered. It is also found that in most cases, there is strong evidence that supports presence for asymmetric adjustments of these series back to their equilibrium. Results for Botswana show that the adjustments of the bilateral exchange rates are asymmetric with all its trading partners considered, apart from Norway and Israel. Appreciation is faster with ten countries than depreciation while the opposite is the case with Belgium and Switzerland. Asymmetric adjustments detected for Ghana real exchange rates are with nine of its trading partners, where appreciation is faster with five countries and depreciation is quicker with three countries. These are Egypt, France and the Netherlands.

Adjustments are asymmetric in case of Ghana with eleven of its trading partners where appreciation is faster in all of them, except with Nigeria, South Africa and the US. Asymmetries in adjustment of Nigeria bilateral exchange rates were recorded for all its trading countries studied, except with Ghana. Nigeria and Ghana have been members of the Economic Community of West African States (ECOWAS), since the mid-1970s. This might be the explanation for the lack of asymmetries in their bilateral exchange rates. Among the asymmetries found, appreciation is faster in six countries and depreciation is quicker in the rest. Nine cases of asymmetric adjustments are found for both South Africa and Tanzania and appreciation is faster in all the cases for the former, except for Botswana. It is worth-noting that Botswana is a very small economy that depends on South Africa for most of its imports. South African economy dominates the whole region, which explains the behaviour of its bilateral exchange rates with Botswana. For Tanzania, the asymmetric adjustments indicate that appreciation is faster with respect of Kenya and the UK while depreciation is faster for the rest of the countries.

\footnotetext{
${ }^{7}$ This indicates the superiority of the test over the symmetric ones as noted by Bohl (2003).
} 
It is evident from the foregoing that appreciation is faster than depreciation in most cases, which means that depreciation or appreciation in adjustment process is not symmetric. This is consistent with the results reported by the sub-literature that looks into differences between the declared (de jure) exchange rate regimes and what the countries do (de facto). It was found that, in general, countries are less tolerant to exchange rate depreciation than appreciation (Calvo \& Reinhart, 2002; Reinhart and Rogoff $(2005) .^{8}$

Overall, the results suggest that accounting for structural breaks led to improved evidence for the PPP hypothesis. This is consistent with a number of papers that emphasize importance of addressing non-linearity and structural breaks in the PPP analysis. Authors that demonstrate this include Narayan et al (2009), Gomez-Zaldirar, et al (2013), Dimitriou and Simos (2013) and Sabate et al (2003).

However, there are two limitations of this paper that needed to be highlighted. First, the LM unit root test used can only accommodate up to two structural breaks. Given the fact that domestic policy changes and external shocks to commodity prices that these countries depend on are frequent, there is a high probability that the breaks could exceed two that the framework allows. This is an apparent limitation, even though, it could be argued that the threshold cointegration can mitigate this to some extent. Secondly, the frequency and the time span of the sample can also obliterate some structural breaks and non-linearity in the data-set. This is, as acknowledged above, a constraint placed by non-availability of data. Therefore, this suggests further analysis when higher frequency and/or longer time span data-set becomes available.

\footnotetext{
${ }^{8}$ This literature argues that countries try to influence the behaviour of their real exchange rate by using monetary policy (changes in money supply or interest rates) and direct intervention in foreign exchange markets.
} 


\section{Conclusion}

This paper has investigated the validity of the PPP using the bilateral real exchange rates of six African countries, namely; Botswana, Ghana, Kenya, Nigeria, South Africa and Tanzania with their fifteen major trading partners. The ADF, the PP and the LM unit root tests of Lee and Strazicich (2003), which accounts for up to two structural breaks in series, were used. In addition, the long-run relationship between the series was also investigated by applying symmetric and asymmetric threshold cointegration of Enders and Siklos (2001).

The results from both the ADF and the PP as well as symmetric cointegration are, generally, mixed. Results from the ADF and the PP tests suggest that the null of unit root is rejected for part of the sub-sample of the six countries studied: 13 countries for Botswana, two countries for Ghana, eleven countries for Kenya and Nigeria, twelve countries for South Africa and six countries for Tanzania. The LM Test, on the other hand, reports additional evidence that supports the existence of the PPP in all the countries covered. The results show that the PPP holds for fourteen countries in respect of South African trading partners and thirteen each for Tanzania and Botswana. For the rest of the countries covered; Ghana, Kenya and Nigeria, the results from the LM Test show that evidence in favour of the PPP exists between these countries' bilateral exchange rates with all their fifteen major trading partners investigated. The identified break dates by the LM Tests coincide with the periods of external shocks, such as terms of trade and oil price shocks. Other break dates correspond to the policy regime shifts during the structural reforms programmes implemented by the countries.

In investigating long-run relationship between the series, results from symmetric cointegration tests could not reject the null of no cointegration for most of the countries. Results from the model that uses the linear cointe- 
gration test show that there is evidence of the long-run PPP for six countries in respect of Botswana whereas results for Ghana and Kenya, the evidence of the long-run PPP exists between the series for only three out of their fifteen major trading partners considered. However, the results found support for the PPP from the linear cointegration test are more for Nigeria and Tanzania. Eight bilateral exchange rates are found to exhibit the long-run relationships. For South Africa, the results indicate presence of evidence in favour of the PPP with only four of its major trading partners. However, the threshold cointegration test shows that the PPP hypothesis is supported in all the countries. This indicates importance of accounting for non-linearity in the study. The study also explores whether adjustments of these bilateral real exchange rates of the countries with their fifteen major trading partners can be captured by linear or asymmetric models. Given the greater likelihood of price and information rigidities in the goods markets of these countries as well as exchange rate market interventions by monetary policy to defend their currencies, particularly from depreciations, it is important to investigate possibilities of nonlinearity in the series. Therefore, possibility of asymmetries in the adjustment mechanism was accounted for.

Threshold cointegration approach suggests that the degree of mean reversion of the series back to equilibrium is generally higher when asymmetries are accounted for. It was generally found that appreciation is faster than depreciation, which supports the view that countries are more intolerant of real exchange rate depreciation than appreciation. The threshold cointegration results show that a long-run relationship exists between the series for all the countries studied along with their fifteen trading partners. This indicates that the linear cointegration approach might be biased in the presence of asymmetries adjustments. 


\section{References}

[1] Bajo-Rubio, O. Diaz-Roldan, C. and Evesteve, V (2004) "Searching for Threshold Effects in the Evolution of Budget Deficits: An Application to the Spanish Case", Economics Letters, 82:2, 239-243.

[2] Balke, N. S. and Thomas B. Fomby (1997) "Threshold Cointegration", International Economic Review, 38: 3, pp. 627-645.

[3] Calvo, Guillermo A. \& Carmen M. Reinhart (2002) "Fear of Floating" The Quarterly Journal of Economics, 117 (2), 379-408.

[4] Chortareas, G. E., G. Kapetanios \& Y. Shin. (2002). "Nonlinear mean reversion in real exchange rates."Economics Letters 77:411-417.

[5] Doganlar, M., Harun Bal \& Mehmet Özmen. (2009). "Testing longrun validity of purchasing power parity for selected emerging market economies", Applied Economics Letters 16(14):1443-1448.

[6] Enders, W. \& K. Chumrusphonlert. (2004). "Threshold cointegration and purchasing power parity in the pacific nations", Applied Economics 36(9):889-896.

[7] Enders, Walter \& Selahattin Dibooglu. (2001). "Long-Run Purchasing Power Parity with Asymmetric Adjustment." Southern Economic Journal 68(2):433-445.

[8] Fleissig, A. R. \& J. Strauss. (2000). "Panel unit root tests of purchasing power parity for price indices." Journal of International Money and Finance 19:489-506.

[9] Flynn, N. A. \& J. L. Boucher. (1993). "Tests of long run purchasing power parity using alternative methodologies." Journal of Macroeconomics 15:109-122.

[10] Frankel, J. A. \& A. K. Rose. (1996). "A panel project on purchasing power parity: mean reversion within and between countries." Journal of International Economics 40:209-224.

[11] GÓMEZ-ZALDÍVAR, M; VENTOSA-SANTAULÀRIA, D; WALLACE, FH. (2013) "The PPP hypothesis and structural breaks: the case of Mexico". Empirical Economics. 45, 3, 1351-1359.

[12] Grilli, V. \& G. Kaminsky. (1991). "Nominal exchange rate regimes and the real exchange rate: evidence from the United States and Great Britain 1885 - 1986." Journal of Monetary Economics 27:191-212. 
[13] Holmes, Mark \& Ping Wang. (2006). "Asymmetric adjustment towards long-run PPP: Some new evidence for Asian economies." International Economic Journal 20(2):161-177.

[14] Karfakis, Costas \& Demetrios Moschos. (1989). "Testing for long run purchasing power parity: A time series analysis for the greek drachma." Economics Letters 30(3):245-248.

[15] Kargbo, J.M. (2006). "Purchasing power parity and real exchange rate behaviour in Africa." Applied Financial Economics, 16(1):169-183.

[16] Karoglou, Michail \& Bruce Morley. (2012). "Purchasing power parity and structural instability in the US/UK exchange rate." Journal of International Financial Markets, Institutions \& Money 22:958-972.

[17] Kilian, L. \& M. P. Taylor. (2003). "Why is it difficult to beat the random walk forecast of exchange rates." Journal of International Economics 60:85-107.

[18] Kim, Yoonbai. (1990). "Purchasing Power Parity in the Long Run: A Cointegration Approach." Journal of Money, Credit and Banking 22(4):491-503.

[19] Lee, Junsoo \& Mark C. Strazicich. (2003). "Minimum Lagrange Multiplier Unit Root Test with Two Structural Breaks." The Review of Economics and Statistics 85(4):1082-1089.

[20] Mahdavi, S \& S Zhou. (1994). "Purchasing power parity in high inflation countries: Further evidence." Journal of Macroeconomics 16:403422 .

[21] Mohammadi, H. (2009) "Electricity Prices and Fuel Costs: Long-Run Relations and Short-Run Dynamics", Energy Economics, 31, 503-509.

[22] Narayan, P. K., Seema Narayan and Arti Prasad (2009) "Evidence on PPP from a cointegration test with multiple structural breaks", Applied Economics Letters 16, Iss. 1, 5-8.

[23] O'Connell, P. (1998). "The overvaluation of purchasing power parity." Journal of International Economics, 44:1-19.

[24] Odedokun, M. O. (2000). "Fulfilment of purchasing power parity conditions in Africa: The differential role of CFA and non-CFA membership." Journal of African Economies 9(2):213-234.

[25] Ono, H. (2014) The government Expenditure-Economic Growth Relation in Japan: An Analysis by using the ADL Test for Threshold Cointegration, Applied Economics, 46:28, 3523-3531. 
[26] Papell, D. H. \& H. Theodoridis. (1998). "Increasing evidence of purchasing power parity over the current Float." Journal of International Money and Finance 17:41-50.

[27] Perron, Pierre. (1989). "The Great Crash, the Oil Price Shock, and the Unit Root Hypothesis." Econometrica 57(6):1361-1401.

[28] Sabaté, M., M-D. Gadea and J-M. Serrano, (2003), "Purchasing power parity and structural breaks: the peseta-sterling rate, 50 years of a floating regime", Journal of International Money and Finance, 22, 61327.

[29] Sarno, L., M. P. Taylor \& I. Chowdhury. (2004). "Nonlinear dynamics in deviations from the law of one price: a broad-based empirical study." Journal of International Money and Finance 23:1-25.

[30] Trachanas, E. and Katrakilidis, C. (2013a) "Fiscal deficits under financial pressure and insolvency: Evidence for Italy, Greece and Spain", Journal of Policy Modeling, Volume 35, Issue 5, 730-749.

[31] Trachanas, E. and Katrakilidis, C. (2013b) "The dynamic linkages of fiscal and current account deficits: New evidence from five highly indebted European countries accounting for regime shifts and asymmetries", Economic Modelling, 31, 502-510.

[32] Taylor, Alan M. (2002). "A Century of Purchasing-Power Parity." The Review of Economic and Statistics 84(1):139-150.

[33] Taylor, M. P., D. A. Peel \& L. Sarno. (2001). "Nonlinear mean reversion in real exchange rates: towards a solution to the purchasing power parity puzzles." International Economic Review 42:1015-1042.

[34] Valadkhani, A. and Majid Nameni, (2011),"How can Iran's black market exchange rate be managed?", Journal of Economic Studies, 38 Iss 2 pp. $186-202$

[35] Yilanci, Veli \& Zehra Ayca Eris. (2013). "Purchasing Power Parity in African Countries: Further Evidence from Fourier Unit Root Tests Based on Linear and Nonlinear Models." South African Journal of Economics 81(1):20-34. 


\begin{tabular}{|c|c|c|c|c|c|}
\hline \multicolumn{6}{|c|}{ Table 1a: Botswana Bilateral Real Exchange Rates } \\
\hline \multicolumn{3}{|c|}{ ADF Unit Root Test } & \multicolumn{3}{|c|}{ PP Unit Root Test } \\
\hline Countries & $\alpha$ & $\beta$ & Countries & $\alpha$ & $\beta$ \\
\hline Belgium $[\mathrm{C}]$ & -0.449 & - & Belgium $[\mathrm{C}]$ & -1.007 & - \\
\hline Belgium $[\mathrm{CT}]$ & -2.548 & $2.296^{* *}$ & Belgium $[\mathrm{CT}]$ & -2.523 & $2.296^{* *}$ \\
\hline Canada $[\mathrm{C}]$ & $-3.958^{*}$ & - & Canada $[\mathrm{C}]$ & $-6.044^{*}$ & - \\
\hline Canada $[\mathrm{CT}]$ & -3.131 & $2.639^{* *}$ & Canada $[\mathrm{CT}]$ & $-6.162^{*}$ & 1.462 \\
\hline China $[\mathrm{C}]$ & $-6.448^{*}$ & - & China $[\mathrm{C}]$ & $-5.901 *$ & - \\
\hline China $[\mathrm{CT}]$ & $-6.849^{*}$ & $1.852^{* * *}$ & China $[\mathrm{CT}]$ & $-6.171^{*}$ & $2.043^{* * *}$ \\
\hline France $[\mathrm{C}]$ & -1.402 & - & France $[\mathrm{C}]$ & $-3.710^{*}$ & - \\
\hline France $[\mathrm{CT}]$ & -1.824 & 1.671 & France $[\mathrm{CT}]$ & $-4.191^{*}$ & $2.002^{* * *}$ \\
\hline India $[\mathrm{C}]$ & $-6.565^{*}$ & - & India $[\mathrm{C}]$ & $-6.726^{*}$ & - \\
\hline India $[\mathrm{CT}]$ & 0.806 & $2.594^{* * *}$ & India $[\mathrm{CT}]$ & $-6.722 *$ & -0.714 \\
\hline Israel $[\mathrm{C}]$ & -1.266 & - & Israel $[\mathrm{C}]$ & -1.736 & - \\
\hline Israel $[\mathrm{CT}]$ & -2.405 & $-2.068^{* *}$ & Israel $[\mathrm{CT}]$ & $-3.273^{* * *}$ & $-2.424^{* *}$ \\
\hline Japan $[\mathrm{C}]$ & -0.328 & - & $\operatorname{Japan}[\mathrm{C}]$ & $-3.191^{* *}$ & - \\
\hline Japan $[\mathrm{CT}]$ & -2.278 & $-2.229^{* *}$ & Japan $[\mathrm{CT}]$ & $-3.795^{* *}$ & $-1.966^{* * *}$ \\
\hline Norway $[\mathrm{C}]$ & -1.820 & - & Norway [C] & $-6.556^{*}$ & - \\
\hline Norway $[\mathrm{CT}]$ & -1.508 & 0.933 & Norway $[\mathrm{CT}]$ & $-6.502^{*}$ & 1.049 \\
\hline South Africa $[\mathrm{C}]$ & $-8.206^{*}$ & - & South Africa $[\mathrm{C}]$ & $-8.206^{*}$ & - \\
\hline South Africa $[\mathrm{CT}]$ & $-3.422^{* * *}$ & 0.995 & South Africa $[\mathrm{CT}]$ & $-8.098^{*}$ & -0.633 \\
\hline Switzerland $[\mathrm{C}]$ & 1.682 & - & Switzerland $[\mathrm{C}]$ & $-5.142^{*}$ & - \\
\hline Switzerland $[\mathrm{CT}]$ & -0.154 & 1.504 & Switzerland $[\mathrm{CT}]$ & $-5.354^{*}$ & $1.769^{* * *}$ \\
\hline Thailand $[\mathrm{C}]$ & $-7.187^{*}$ & - & Thailand $[\mathrm{C}]$ & $-7.289^{*}$ & - \\
\hline Thailand $[\mathrm{CT}]$ & $-7.248^{*}$ & 0.979 & Thailand $[\mathrm{CT}]$ & $-7.749^{*}$ & $1.867^{* * *}$ \\
\hline United Kingdom [C] & $-3.595^{* *}$ & - & United Kingdom [C] & $-6.673^{*}$ & - \\
\hline United Kingdom $[\mathrm{CT}]$ & $-3.576^{* *}$ & 0.509 & United Kingdom $[\mathrm{CT}]$ & $-6.583^{*}$ & 0.491 \\
\hline USA $[\mathrm{C}]$ & $-2.867^{* * *}$ & - & USA $[\mathrm{C}]$ & $-5.611 *$ & - \\
\hline USA [CT] & $-3.446^{* * *}$ & $1.803^{* * *}$ & USA $[\mathrm{CT}]$ & $-6.455^{*}$ & $2.979^{*}$ \\
\hline Zambia $[\mathrm{C}]$ & -0.906 & - & Zambia $[\mathrm{C}]$ & -1.847 & - \\
\hline Zambia $[\mathrm{CT}]$ & $-6.052^{*}$ & $-4.594^{*}$ & Zambia $[\mathrm{CT}]$ & $-4.412^{*}$ & $-3.535^{*}$ \\
\hline Zimbabwe $[\mathrm{C}]$ & $-4.633^{*}$ & - & Zimbabwe $[\mathrm{C}]$ & $-4.912^{*}$ & - \\
\hline Zimbabwe $[\mathrm{CT}]$ & $-6.463^{*}$ & $-3.821^{*}$ & Zimbabwe $[\mathrm{CT}]$ & $-6.461^{*}$ & -3.821 \\
\hline \multicolumn{6}{|c|}{$\begin{array}{l}\text { Notes: }{ }^{*}, * * \text { and }{ }^{* * *} \text { signify rejections at } 1 \%, 5 \% \text { and } 10 \% \text {, respectively. } \\
\alpha \text { and } \beta \text { are the estimated test statistic for unit root and trend respectively } \\
\mathrm{ADF}=\text { Augmented Dickey Fuller test, } \mathrm{PP}=\text { Philip-Perrons test } \\
\mathrm{C}=\text { Model with constant, } \mathrm{CT}=\text { Model with constant and linear trend }\end{array}$} \\
\hline
\end{tabular}




\begin{tabular}{|c|c|c|c|c|c|}
\hline \multicolumn{6}{|c|}{ Table 1b Ghana Bilateral Real Exchange Rates } \\
\hline \multicolumn{3}{|c|}{ ADF unit Root Test } & \multicolumn{3}{|c|}{ PP unit Root Test } \\
\hline Countries & $\alpha$ & $\beta$ & Countries & $\alpha$ & $\beta$ \\
\hline Algeria $[\mathrm{C}]$ & -1.005 & - & Algeria $[\mathrm{C}]$ & -0.775 & - \\
\hline Algeria $[\mathrm{CT}]$ & -3.173 & $3.004^{*}$ & Algeria $[\mathrm{CT}]$ & -3.183 & $3.004^{*}$ \\
\hline Canada $[\mathrm{C}]$ & -0.275 & - & Canada $[\mathrm{C}]$ & 0.432 & - \\
\hline Canada $[\mathrm{CT}]$ & -3.108 & $3.213^{*}$ & Canada $[\mathrm{CT}]$ & -2.952 & $3.211^{*}$ \\
\hline China $[\mathrm{C}]$ & $-6.362^{*}$ & - & China $[\mathrm{C}]$ & -6.366 & - \\
\hline China $[\mathrm{CT}]$ & $6.724^{*}$ & $1.739^{* * *}$ & China $[\mathrm{CT}]$ & -6.717 & $1.739^{* * *}$ \\
\hline France $[\mathrm{C}]$ & 0.643 & - & France $[\mathrm{C}]$ & 0.572 & - \\
\hline France $[\mathrm{CT}]$ & -2.962 & $3.198^{*}$ & France $[\mathrm{CT}]$ & -2.727 & $3.198^{*}$ \\
\hline India $[\mathrm{C}]$ & -1.754 & - & India $[\mathrm{C}]$ & -0.711 & - \\
\hline India $[\mathrm{CT}]$ & $-3.322^{* * *}$ & $3.138^{*}$ & India $[\mathrm{CT}]$ & -3.128 & $3.138^{*}$ \\
\hline Japan $[\mathrm{C}]$ & -0.151 & - & Japan $[\mathrm{C}]$ & 0.412 & - \\
\hline Japan $[\mathrm{CT}]$ & $-3.330 * * *$ & $3.311^{*}$ & Japan $[\mathrm{CT}]$ & -2.168 & $2.904^{*}$ \\
\hline Malaysia $[\mathrm{C}]$ & $-2.912^{* * *}$ & - & Malaysia $[\mathrm{C}]$ & $-4.041^{*}$ & - \\
\hline Malaysia $[\mathrm{CT}]$ & $-4.743^{*}$ & $2.414^{* *}$ & Malaysia $[\mathrm{CT}]$ & $-4.811^{*}$ & $2.415^{* *}$ \\
\hline Nigeria $[\mathrm{C}]$ & -0.712 & - & Nigeria $[\mathrm{C}]$ & -2.015 & - \\
\hline Nigeria $[\mathrm{CT}]$ & 3.099 & $2.277^{* *}$ & Nigeria $[\mathrm{CT}]$ & -2.987 & $2.277^{* *}$ \\
\hline Norway $[\mathrm{C}]$ & 0.493 & - & Norway $[\mathrm{C}]$ & -0.037 & - \\
\hline Norway [CT] & -3.036 & $3.113^{*}$ & Norway [CT] & -3.036 & $3.113^{*}$ \\
\hline Singapore $[C]$ & -2.253 & - & Singapore [C] & -0.190 & - \\
\hline Singapore $[\mathrm{CT}]$ & $-8.294^{*}$ & $5.594^{*}$ & Singapore $[\mathrm{CT}]$ & $-4.729 *$ & $4.765^{*}$ \\
\hline South Africa $[\mathrm{C}]$ & -0.384 & - & South Africa $[\mathrm{C}]$ & -0.195 & - \\
\hline South Africa $[\mathrm{CT}]$ & -2.842 & 2.889 & South Africa $[\mathrm{CT}]$ & -2.842 & $2.889^{*}$ \\
\hline Switzerland $[\mathrm{C}]$ & -0.786 & - & Switzerland $[\mathrm{C}]$ & -0.547 & - \\
\hline Switzerland $[\mathrm{CT}]$ & -2.786 & $2.698^{*}$ & Switzerland $[\mathrm{CT}]$ & -2.786 & $2.698^{*}$ \\
\hline Turkey $[\mathrm{C}]$ & -2.405 & - & Turkey $[\mathrm{C}]$ & $-2.630 * * *$ & - \\
\hline Turkey $[\mathrm{CT}]$ & -2.761 & -1.508 & Turkey $[\mathrm{CT}]$ & $-3.211^{* * *}$ & $-2.146^{* *}$ \\
\hline $\mathrm{UK}[\mathrm{C}]$ & -0.235 & - & $\mathrm{UK}[\mathrm{C}]$ & 0.147 & - \\
\hline $\mathrm{UK}[\mathrm{CT}]$ & -2.993 & $3.152^{*}$ & $\mathrm{UK}[\mathrm{CT}]$ & -2.845 & $3.152^{*}$ \\
\hline USA $[\mathrm{C}]$ & 0.063 & - & USA $[\mathrm{C}]$ & 0.538 & - \\
\hline USA $[\mathrm{CT}]$ & 2.872 & $3.098^{*}$ & USA $[\mathrm{CT}]$ & -2.743 & $3.098^{*}$ \\
\hline
\end{tabular}




\begin{tabular}{|c|c|c|c|c|c|}
\hline \multicolumn{6}{|c|}{ Table 1c Kenya Bilateral Real Exchange Rates } \\
\hline \multicolumn{3}{|c|}{ ADF Unit Root Tests } & \multicolumn{3}{|c|}{ PP Unit Root Tests ' } \\
\hline Countries & $\alpha$ & $\beta$ & Countries & $\alpha$ & $\bar{\beta}$ \\
\hline China $[\mathrm{C}]$ & $-4.202^{*}$ & - & China $[\mathrm{C}]$ & $-4.275^{*}$ & - \\
\hline China $[\mathrm{CT}]$ & $-5.206^{*}$ & $2.774^{*}$ & China $[\mathrm{CT}]$ & $-5.207^{*}$ & $2.774^{*}$ \\
\hline Egypt [C] & $-4.747^{*}$ & - & Egypt [C] & $-4.815^{*}$ & - \\
\hline Egypt $[\mathrm{CT}]$ & $-4.607^{*}$ & -0.175 & Egypt $[\mathrm{CT}]$ & $-4.690^{*}$ & -0.175 \\
\hline France $[\mathrm{C}]$ & -2.491 & - & France $[\mathrm{C}]$ & -2.491 & - \\
\hline France $[\mathrm{CT}]$ & -2.588 & 0.924 & France $[\mathrm{CT}]$ & -2.483 & 0.924 \\
\hline India $[\mathrm{C}]$ & $-4.078^{*}$ & - & India $[\mathrm{C}]$ & $-4.056^{*}$ & - \\
\hline India $[\mathrm{CT}]$ & $-4.122^{*}$ & -0.796 & India $[\mathrm{CT}]$ & $-4.101^{* *}$ & -0.795 \\
\hline Japan $[C]$ & -2.647 & - & Japan $[\mathrm{C}]$ & -2.683 & - \\
\hline Japan $[\mathrm{CT}]$ & -3.038 & 1.096 & Japan $[\mathrm{CT}]$ & -3.003 & -1.317 \\
\hline Malaysia $[\mathrm{C}]$ & -5.361 & - & Malaysia $[\mathrm{C}]$ & $-5.961^{*}$ & - \\
\hline Malaysia $[\mathrm{CT}]$ & $-7.007^{*}$ & $3.621^{*}$ & Malaysia $[\mathrm{CT}]$ & $-6.415^{*}$ & $1.980^{* * *}$ \\
\hline Netherlands [C] & -1.931 & - & Netherlands $[\mathrm{C}]$ & -1.886 & - \\
\hline Netherlands [CT] & 1.892 & 0.691 & Netherlands [CT] & -1.850 & 0.691 \\
\hline Pakistan $[\mathrm{C}]$ & $-5.253^{*}$ & - & Pakistan $[\mathrm{C}]$ & $-5.152^{*}$ & - \\
\hline Pakistan $[\mathrm{CT}]$ & $-5.264^{*}$ & -0.667 & Pakistan $[\mathrm{CT}]$ & $-5.003^{*}$ & 0.375 \\
\hline Saudi Arabia $[\mathrm{C}]$ & $-4.239^{*}$ & - & Saudi Arabia $[\mathrm{C}]$ & $-4.314^{*}$ & - \\
\hline Saudi Arabia $[\mathrm{CT}]$ & $-4.540^{*}$ & 1.512 & Saudi Arabia $[\mathrm{CT}]$ & $-4.435^{*}$ & 1.512 \\
\hline Singapore $[\mathrm{C}]$ & $-4.408^{*}$ & - & Singapore $[\mathrm{C}]$ & $-4.423^{*}$ & - \\
\hline Singapore $[\mathrm{CT}]$ & $-5.419 *$ & $2.719^{*}$ & Singapore $[\mathrm{CT}]$ & $-5.347^{*}$ & $2.611^{* *}$ \\
\hline South Africa [C] & $-7.476^{*}$ & - & South Africa $[\mathrm{C}]$ & $-4.786^{*}$ & - \\
\hline South Africa $[\mathrm{CT}]$ & $-7.489^{*}$ & -0.805 & South Africa $[\mathrm{CT}]$ & $-5.026^{*}$ & $-1.807 * * *$ \\
\hline Spain $[C]$ & -1.513 & - & Spain $[C]$ & -1.374 & - \\
\hline Spain $[\mathrm{CT}]$ & -1.657 & 0.772 & Spain $[\mathrm{CT}]$ & -1.496 & 0.772 \\
\hline Thailand $[\mathrm{C}]$ & $-5.145^{*}$ & - & Thailand $[\mathrm{C}]$ & $-5.470^{*}$ & - \\
\hline Thailand $[\mathrm{CT}]$ & $-5.362^{*}$ & 1.388 & Thailand [CT] & $-5.195^{*}$ & 0.354 \\
\hline $\mathrm{UK}[\mathrm{C}]$ & $-4.294^{*}$ & - & $\mathrm{UK}[\mathrm{C}]$ & $-4.294^{*}$ & - \\
\hline $\mathrm{UK}[\mathrm{CT}]$ & $-4.199^{*}$ & 0.100 & $\mathrm{UK}[\mathrm{CT}]$ & $-4.199^{* *}$ & 0.100 \\
\hline $\mathrm{USA}[\mathrm{C}]$ & $-3.092^{* *}$ & - & USA [C] & $-3.091^{* *}$ & - \\
\hline USA $[\mathrm{CT}]$ & -2.859 & 0.879 & USA [CT] & -2.859 & 0.879 \\
\hline
\end{tabular}




\begin{tabular}{|c|c|c|c|c|c|}
\hline \multicolumn{6}{|c|}{ Table 1d Nigeria Bilateral Real Exchange Rates } \\
\hline \multicolumn{3}{|c|}{ ADF Unit Root Test } & \multicolumn{3}{|c|}{ PP Unit Root Test } \\
\hline Countries & $\alpha$ & $\bar{\beta}$ & Countries & $\alpha$ & $\beta$ \\
\hline Australia $[\mathrm{C}]$ & -0.575 & - & Australia $[\mathrm{C}]$ & -1.083 & - \\
\hline Australia $[\mathrm{CT}]$ & -1.869 & $1.839^{* * *}$ & Australia $[\mathrm{CT}]$ & $-3.413^{* * *}$ & $3.304^{*}$ \\
\hline Canada [C] & -1.609 & - & Canada [C] & -1.367 & - \\
\hline Canada $[\mathrm{CT}]$ & $-3.755^{* *}$ & $3.411^{*}$ & Canada $[\mathrm{CT}]$ & $-3.673^{* *}$ & $3.411^{*}$ \\
\hline China $[\mathrm{C}]$ & -0.205 & - & China $[\mathrm{C}]$ & -1.175 & - \\
\hline China $[\mathrm{CT}]$ & $-3.597^{* *}$ & $3.343^{*}$ & China $[\mathrm{CT}]$ & -3.027 & $2.684^{* *}$ \\
\hline Ivory Coast $[\mathrm{C}]$ & -1.896 & - & Ivory Coast $[\mathrm{C}]$ & -1.686 & - \\
\hline Ivory Coast $[\mathrm{CT}]$ & $-3.220^{* * *}$ & $3.268^{*}$ & Ivory Coast $[\mathrm{CT}]$ & $-3.920^{* *}$ & $3.187^{*}$ \\
\hline Ghana $[\mathrm{C}]$ & -0.712 & - & Ghana $[\mathrm{C}]$ & -1.700 & - \\
\hline Ghana $[\mathrm{CT}]$ & $-3.224^{* * *}$ & $-2.574^{* *}$ & Ghana $[\mathrm{CT}]$ & -3.139 & $-2.574^{* *}$ \\
\hline India $[\mathrm{C}]$ & -2.644 & - & India $[\mathrm{C}]$ & -2.644 & - \\
\hline India $[\mathrm{CT}]$ & $-4.183^{*}$ & $3.555^{*}$ & India $[\mathrm{CT}]$ & $-4.451^{*}$ & $3.805^{*}$ \\
\hline Indonesia $[\mathrm{C}]$ & -2.393 & - & Indonesia $[\mathrm{C}]$ & -2.186 & - \\
\hline Indonesia $[\mathrm{CT}]$ & $-3.577^{* *}$ & $2.552^{* *}$ & Indonesia $[\mathrm{CT}]$ & $-3.491^{* * *}$ & $2.552^{* *}$ \\
\hline Japan $[\mathrm{C}]$ & -2.098 & - & Japan $[\mathrm{C}]$ & -2.061 & - \\
\hline Japan $[\mathrm{CT}]$ & -2.203 & $2.199^{* *}$ & Japan $[\mathrm{CT}]$ & -3.028 & $2.491^{* *}$ \\
\hline South Korea $[\mathrm{C}]$ & -1.243 & - & South Korea $[\mathrm{C}]$ & -0.998 & - \\
\hline South Korea $[\mathrm{CT}]$ & -2.685 & $2.616^{* *}$ & South Korea $[\mathrm{CT}]$ & -2.722 & $2.662^{* *}$ \\
\hline South Africa $[\mathrm{C}]$ & -2.028 & - & South Africa $[\mathrm{C}]$ & -1.843 & - \\
\hline South Africa $[\mathrm{CT}]$ & $-5.233^{*}$ & $4.495^{*}$ & South Africa $[\mathrm{CT}]$ & $-4.942^{*}$ & $4.238^{*}$ \\
\hline Switzerland $[\mathrm{C}]$ & -2.104 & - & Switzerland $[\mathrm{C}]$ & -2.104 & - \\
\hline Switzerland $[\mathrm{CT}]$ & $-4.004^{* *}$ & $3.275^{* 6}$ & Switzerland $[\mathrm{CT}]$ & $-3.977^{* *}$ & $3.275^{*}$ \\
\hline Thailand [C] & -2.623 & - & Thailand $[\mathrm{C}]$ & -2.623 & - \\
\hline Thailand $[\mathrm{CT}]$ & $-3.911^{* *}$ & $2.743^{* *}$ & Thailand $[\mathrm{CT}]$ & $-3.911^{* *}$ & $2.742^{*}$ \\
\hline Turkey $[\mathrm{C}]$ & -0.832 & - & Turkey $[\mathrm{C}]$ & -0.446 & - \\
\hline Turkey $[\mathrm{CT}]$ & $-4.144^{* *}$ & $-4.115^{*}$ & Turkey $[\mathrm{CT}]$ & $-4.135^{* *}$ & $-4.115^{*}$ \\
\hline $\mathrm{UK}[\mathrm{C}]$ & -1.467 & - & $\mathrm{UK}[\mathrm{C}]$ & -1.364 & - \\
\hline $\mathrm{UK}[\mathrm{CT}]$ & $-3.621^{* * *}$ & $3.420^{*}$ & $\mathrm{UK}[\mathrm{CT}]$ & $-3.609^{* *}$ & $3.420 *$ \\
\hline $\mathrm{USA}[\mathrm{C}]$ & -0.664 & - & $\mathrm{USA}[\mathrm{C}]$ & -0.261 & - \\
\hline USA $[\mathrm{CT}]$ & $-3.550^{* * *}$ & $3.754^{*}$ & USA $[\mathrm{CT}]$ & $3.555^{* *}$ & $3.754^{*}$ \\
\hline
\end{tabular}




\begin{tabular}{|c|c|c|c|c|c|}
\hline \multicolumn{6}{|c|}{ Table1e South Africa Bilateral Real Exchange Rates } \\
\hline \multicolumn{3}{|c|}{ ADF Unit Root Tests } & \multicolumn{3}{|c|}{ ADF Unit Root Tests } \\
\hline Countries & $\alpha$ & $\beta$ & Countries & $\alpha$ & $\beta$ \\
\hline Botswana $[\mathrm{C}]$ & $-8.206^{*}$ & - & Botswana $[\mathrm{C}]$ & $-8.206^{*}$ & - \\
\hline Botswana $[\mathrm{CT}]$ & $-3.422^{* * *}$ & -0.955 & Botswana $[\mathrm{CT}]$ & $-8.098^{*}$ & 0.633 \\
\hline Canada $[\mathrm{C}]$ & $-3.264^{* * *}$ & - & Canada $[\mathrm{C}]$ & $-3.263^{* * *}$ & - \\
\hline Canada $[\mathrm{CT}]$ & $-3.915^{* *}$ & $2.020^{* *}$ & Canada $[\mathrm{CT}]$ & $-3.831^{* *}$ & $2.020^{* *}$ \\
\hline China $[\mathrm{C}]$ & $-5.795^{*}$ & - & China $[\mathrm{C}]$ & $-5.785^{*}$ & - \\
\hline China $[\mathrm{CT}]$ & $-5.980 *$ & $3.140^{*}$ & China $[\mathrm{CT}]$ & $-6.600^{*}$ & $2.513^{* *}$ \\
\hline France $[\mathrm{C}]$ & -1.779 & - & France $[\mathrm{C}]$ & -1.467 & - \\
\hline France $[\mathrm{CT}]$ & -2.578 & $1.938^{* * *}$ & France $[\mathrm{CT}]$ & -2.382 & $1.938^{* * *}$ \\
\hline India $[\mathrm{C}]$ & -2.029 & - & India $[\mathrm{C}]$ & $-3.650^{*}$ & - \\
\hline India $[\mathrm{CT}]$ & $-3.611^{* *}$ & 0.389 & India $[\mathrm{CT}]$ & $-3.600 * *$ & 0.389 \\
\hline Japan $[\mathrm{C}]$ & $-3.532^{* *}$ & - & Japan $[\mathrm{C}]$ & $-3.561^{* *}$ & - \\
\hline Japan $[\mathrm{CT}]$ & $-3.227^{* * *}$ & -0.137 & Japan $[\mathrm{CT}]$ & $-3.277^{* * *}$ & -0.137 \\
\hline Kenya $[\mathrm{C}]$ & $-4.786^{*}$ & - & Kenya $[\mathrm{C}]$ & $-4.786^{*}$ & - \\
\hline Kenya $[\mathrm{CT}]$ & $-5.167^{*}$ & $1.807^{* * *}$ & Kenya $[\mathrm{CT}]$ & $-5.026^{*}$ & $1.807^{* * *}$ \\
\hline Netherlands [C] & -0.044 & - & Netherlands $[\mathrm{C}]$ & 0.037 & - \\
\hline Netherlands [CT] & -0.511 & 0.687 & Netherlands $[\mathrm{CT}]$ & -0.428 & 0.687 \\
\hline Nigeria $[\mathrm{C}]$ & -2.029 & - & Nigeria $[\mathrm{C}]$ & -1.843 & - \\
\hline Nigeria $[\mathrm{CT}]$ & $-5.234^{*}$ & $-4.495^{*}$ & Nigeria $[\mathrm{CT}]$ & $-4.942^{*}$ & $-4.238^{*}$ \\
\hline Switzerland $[\mathrm{C}]$ & $-3.464^{* *}$ & - & Switzerland $[\mathrm{C}]$ & $-3.455^{* *}$ & - \\
\hline Switzerland $[\mathrm{CT}]$ & $-4.113^{* *}$ & $2.026^{* *}$ & Switzerland $[\mathrm{CT}]$ & $-4.078^{* *}$ & $2.026^{* *}$ \\
\hline Thailand $[\mathrm{C}]$ & $-5.393^{*}$ & - & Thailand $[\mathrm{C}]$ & $-5.026^{*}$ & - \\
\hline Thailand $[\mathrm{CT}]$ & $-5.624^{*}$ & 1.437 & Thailand $[\mathrm{CT}]$ & $-5.226^{*}$ & 1.445 \\
\hline Turkey [C] & 0.328 & - & Turkey [C] & 0.835 & - \\
\hline Turkey [CT] & $-3.608^{* *}$ & $-4.003^{*}$ & Turkey [CT] & $-3.628^{* *}$ & $-4.003^{*}$ \\
\hline $\mathrm{UK}[\mathrm{C}]$ & $-2.810^{* * *}$ & - & $\mathrm{UK}[\mathrm{C}]$ & $-2.745^{* * *}$ & - \\
\hline $\mathrm{UK}[\mathrm{CT}]$ & -3.145 & 1.467 & $\mathrm{UK}[\mathrm{CT}]$ & -3.054 & 1.467 \\
\hline USA [C] & -0.929 & - & USA [C] & -1.443 & - \\
\hline USA $[\mathrm{CT}]$ & -2.830 & $2.293^{* *}$ & $\mathrm{USA}[\mathrm{CT}]$ & -2.732 & $2.293^{* *}$ \\
\hline Zambia $[\mathrm{C}]$ & -1.352 & - & Zambia $[\mathrm{C}]$ & -0.767 & - \\
\hline Zambia $[\mathrm{CT}]$ & $-3.745^{* *}$ & $-3.469 *$ & Zambia $[\mathrm{CT}]$ & $-3.258^{* * *}$ & $-3.282^{*}$ \\
\hline
\end{tabular}




\begin{tabular}{|c|c|c|c|c|c|}
\hline \multicolumn{6}{|c|}{ Table 1f Tanzania Bilateral Real Exchange Rates } \\
\hline \multicolumn{3}{|c|}{ ADF Unit Root Tests } & \multicolumn{3}{|c|}{ PP Unit Root Tests } \\
\hline Countries & $\alpha$ & $\beta$ & Countries & $\alpha$ & $\beta$ \\
\hline Bahrain $[\mathrm{C}]$ & $-3.370^{* *}$ & - & Bahrain $[\mathrm{C}]$ & $-3.226^{* *}$ & - \\
\hline Bahrain $[\mathrm{CT}]$ & $-3.548^{* *}$ & 1.182 & Bahrain $[\mathrm{CT}]$ & $-3.417^{* * *}$ & 1.182 \\
\hline China $[\mathrm{C}]$ & -1.184 & - & China $[\mathrm{C}]$ & -1.830 & - \\
\hline China $[\mathrm{CT}]$ & $-5.001 *$ & $4.285^{*}$ & China $[\mathrm{CT}]$ & $-5.001^{*}$ & $4.284^{*}$ \\
\hline India $[\mathrm{C}]$ & -1.260 & - & India $[\mathrm{C}]$ & -0.976 & - \\
\hline India $[\mathrm{CT}]$ & -1.116 & 0.706 & India $[\mathrm{CT}]$ & $-4.152^{* *}$ & $4.020^{*}$ \\
\hline Indonesia $[\mathrm{C}]$ & -2.381 & - & Indonesia $[\mathrm{C}]$ & -2.476 & - \\
\hline Indonesia $[\mathrm{CT}]$ & $-3.419 * * *$ & $2.542^{* *}$ & Indonesia $[\mathrm{CT}]$ & $-3.409 * * *$ & $2.542^{* *}$ \\
\hline Japan $[\mathrm{C}]$ & -1.008 & - & Japan $[\mathrm{C}]$ & -1.008 & - \\
\hline Japan $[\mathrm{CT}]$ & -2.091 & $2.203^{* *}$ & Japan $[\mathrm{CT}]$ & -2.095 & $2.203^{* *}$ \\
\hline Kenya $[\mathrm{C}]$ & -0.587 & - & Kenya $[\mathrm{C}]$ & -0.232 & - \\
\hline Kenya $[\mathrm{CT}]$ & -2.927 & $3.084^{*}$ & Kenya $[\mathrm{CT}]$ & -2.927 & $3.084^{*}$ \\
\hline South Korea $[\mathrm{C}]$ & -1.169 & - & South Korea $[\mathrm{C}]$ & -1.169 & - \\
\hline South Korea $[\mathrm{CT}]$ & -2.146 & $1.832^{* * *}$ & South Korea $[\mathrm{CT}]$ & -2.146 & $1.832^{* * *}$ \\
\hline Malaysia $[\mathrm{C}]$ & -1.406 & - & Malaysia $[\mathrm{C}]$ & -1.406 & - \\
\hline Malaysia $[\mathrm{CT}]$ & -2.606 & $2.156^{* *}$ & Malaysia $[\mathrm{CT}]$ & -2.540 & $2.156^{* *}$ \\
\hline Saudi Arabia $[\mathrm{C}]$ & -1.613 & - & Saudi Arabia $[\mathrm{C}]$ & -1.430 & - \\
\hline Saudi Arabia $[\mathrm{CT}]$ & -2.806 & $2.275^{* *}$ & Saudi Arabia [CT] & -2.808 & $2.275^{* *}$ \\
\hline Singapore $[\mathrm{C}]$ & -0.696 & - & Singapore $[\mathrm{C}]$ & -1.663 & - \\
\hline Singapore $[\mathrm{CT}]$ & $-4.722^{*}$ & $4.002^{*}$ & Singapore $[\mathrm{CT}]$ & $-4.728^{*}$ & $4.002^{*}$ \\
\hline South Africa [C] & -1.429 & - & South Africa $[\mathrm{C}]$ & -1.286 & - \\
\hline South Africa $[\mathrm{CT}]$ & -2.926 & $2.522^{* *}$ & South Africa $[\mathrm{CT}]$ & -2.966 & $2.522^{* *}$ \\
\hline Switzerland $[\mathrm{C}]$ & -1.524 & - & Switzerland [C] & -1.329 & - \\
\hline Switzerland $[\mathrm{CT}]$ & $-3.283^{* * *}$ & $2.838^{*}$ & Switzerland $[\mathrm{CT}]$ & $-3.270^{* * *}$ & $2.838^{*}$ \\
\hline Turkey $[\mathrm{C}]$ & -0.470 & - & Turkey $[\mathrm{C}]$ & -0.142 & - \\
\hline Turkey $[\mathrm{CT}]$ & -2.729 & $-2.838^{*}$ & Turkey $[\mathrm{CT}]$ & -2.557 & $-2.838^{*}$ \\
\hline $\mathrm{UK}[\mathrm{C}]$ & -0.910 & - & $\mathrm{UK}[\mathrm{C}]$ & -0.895 & - \\
\hline $\mathrm{UK}[\mathrm{CT}]$ & -2.411 & $2.034^{* *}$ & $\mathrm{UK}[\mathrm{CT}]$ & -2.247 & $2.014^{* *}$ \\
\hline $\mathrm{USA}[\mathrm{C}]$ & -0.509 & - & USA [C] & -0.501 & - \\
\hline USA $[\mathrm{CT}]$ & -1.968 & 1.938 & USA $[\mathrm{CT}]$ & -2.008 & $1.938^{* *}$ \\
\hline
\end{tabular}




\begin{tabular}{|c|c|c|c|c|c|c|c|c|c|}
\hline \multicolumn{10}{|c|}{ Table 2a: LM Tests } \\
\hline \multicolumn{10}{|c|}{ Botswana Bilateral Real Exchange Rates } \\
\hline Countries & $T B$ & $\alpha$ & $k$ & $\lambda$ & $T B_{1}$ & $T B_{2}$ & $\alpha$ & $k$ & $\lambda$ \\
\hline Belgium & 1996 & $-5.232^{*}$ & 0 & 0.40 & 1972 & 1998 & $-7.717^{*}$ & 8 & $0.2,0.4$ \\
\hline Canada & 1990 & $-4.215^{* * *}$ & 5 & 0.30 & 1971 & 1994 & $-6.877^{*}$ & 0 & $0.2,0.4$ \\
\hline China & 1976 & $-6.874^{*}$ & 0 & 0.20 & 1972 & 1976 & $-7.527^{*}$ & 0 & $0.2,0.4$ \\
\hline France & 1996 & $-7.021^{*}$ & 0 & 0.40 & 1976 & 1999 & $-12.782^{*}$ & 8 & $0.2,0.4$ \\
\hline India & 1999 & $-4.722^{* *}$ & 0 & 0.40 & 1983 & 1992 & $-11.230^{*}$ & 8 & $0.2,0.4$ \\
\hline Israel & 1982 & -3.822 & 3 & 0.30 & 1973 & 1985 & $-8.789^{*}$ & 0 & $0.2,0.4$ \\
\hline Japan & 1982 & $-7.749^{*}$ & 3 & 0.30 & 1972 & 1983 & $-126.906^{*}$ & 8 & $0.2,0.4$ \\
\hline Norway & 1994 & $-5.067^{*}$ & 3 & 0.40 & 1982 & 1995 & $-9.259^{*}$ & 0 & $0.2,0.4$ \\
\hline South Africa & 1999 & $-5.694^{*}$ & 0 & 0.40 & 1976 & 1998 & $-11.696^{*}$ & 8 & $0.2,0.4$ \\
\hline Switzerland & 1999 & $-7.672^{*}$ & 7 & 0.40 & 1976 & 1999 & $-13.901^{*}$ & 7 & $0.2,0.4$ \\
\hline Thailand & 1982 & $-7.660^{*}$ & 0 & 0.30 & 1972 & 2002 & $-17.212^{*}$ & 8 & $0.2,0.6$ \\
\hline UK & 1995 & $-8.674 *$ & 0 & 0.40 & 1980 & 1999 & $-10.403^{*}$ & 8 & $0.2,0.4$ \\
\hline USA & 1996 & $-8.232^{*}$ & 0 & 0.40 & 1987 & 1998 & $-10.388^{*}$ & 7 & $0.2,0.4$ \\
\hline Zambia & 1989 & $-180.221^{*}$ & 8 & 0.30 & 1989 & 2004 & $-10228.77^{*}$ & 8 & $0.2,0.6$ \\
\hline Zimbabwe & 2003 & $-6.302^{*}$ & 0 & 0.50 & 1972 & 1999 & $-7.232^{*}$ & 0 & $0.2,0.4$ \\
\hline \multicolumn{10}{|c|}{ Ghana Bilateral Real Exchange Rates } \\
\hline Countries & $T B$ & $\alpha$ & $k$ & $\lambda$ & $T B_{1}$ & $T B_{2}$ & $\alpha$ & $k$ & $\lambda$ \\
\hline Algeria & 1982 & $-7.165^{*}$ & 7 & 0.20 & 1983 & 1994 & $-417.897^{*}$ & 8 & $0.2,0.4$ \\
\hline Canada & 1984 & $-4.384^{* * *}$ & 0 & 0.20 & 1982 & 1992 & $-5.708^{* *}$ & 7 & $0.2,0.4$ \\
\hline China & 1978 & $-8.833^{*}$ & 1 & 0.20 & 1978 & 1985 & $-9.088^{*}$ & 1 & $0.2,0.4$ \\
\hline France & 1979 & $-4.709^{* *}$ & 0 & 0.20 & 1976 & 1993 & $-5.348 * * *$ & 8 & $0.2,0.4$ \\
\hline India & 1993 & $-4.229 * * *$ & 8 & 0.30 & 1974 & 1992 & $-7.655^{*}$ & 0 & $0.2,0.4$ \\
\hline Japan & 1979 & $-5.348^{*}$ & 1 & 0.20 & 1981 & 1984 & $-12.137^{*}$ & 7 & $0.2,0.4$ \\
\hline Malaysia & 1983 & $-4.722^{* *}$ & 5 & 0.20 & 1975 & 1993 & $-18.889^{*}$ & 5 & $0.2,0.4$ \\
\hline Nigeria & 1993 & $-4.731^{* *}$ & 6 & 0.30 & 1982 & 1997 & $-6.554^{*}$ & 1 & $0.2,0.4$ \\
\hline Norway & 1983 & $-5.083^{*}$ & 0 & 0.20 & 1979 & 1984 & $-6.680^{*}$ & 0 & $0.2,0.4$ \\
\hline Singapore & 1983 & $-8.720^{*}$ & 0 & 0.20 & 1974 & 1977 & $-9.229^{*}$ & 0 & $0.2,0.4$ \\
\hline South Africa & 1984 & -4.143 & 0 & 0.20 & 1982 & 1992 & $-7.603^{*}$ & 5 & $0.2,0.4$ \\
\hline Switzerland & 1984 & -3.760 & 5 & 0.20 & 1975 & 1992 & $-5.451 * * *$ & 0 & $0.2,0.4$ \\
\hline Turkey & 1993 & $-4.390^{* * *}$ & 0 & 0.30 & 1982 & 1993 & $-5.416^{* * *}$ & 8 & $0.2,0.4$ \\
\hline UK & 1984 & $-5.280^{*}$ & 0 & 0.20 & 1982 & 1992 & $-5.660^{* *}$ & 5 & $0.2,0.4$ \\
\hline USA & 1983 & $-4.342^{* * *}$ & 6 & 0.20 & 1981 & 1985 & $-7.303^{*}$ & 8 & $0.2,0.4$ \\
\hline
\end{tabular}




\begin{tabular}{|c|c|c|c|c|c|c|c|c|c|}
\hline \multicolumn{10}{|c|}{ Table 2b LM Tests } \\
\hline \multicolumn{10}{|c|}{ Kenya Bilateral Real Exchange Rates } \\
\hline Countries & $T B$ & $\alpha$ & $k$ & $\lambda$ & $T B_{1}$ & $T B_{2}$ & $\alpha$ & $k$ & $\lambda$ \\
\hline China & 1984 & $-4.279^{* * *}$ & 0 & 0.20 & 1978 & 1994 & $-5.925^{* *}$ & 4 & $0.2,0.4$ \\
\hline Egypt & 1986 & -4.062 & 0 & 0.30 & 1971 & 1988 & $-5.773^{* *}$ & 0 & $0.2,0.4$ \\
\hline France & 1982 & -3.812 & 0 & 0.20 & 1979 & 1994 & $-5.686^{* *}$ & 6 & $0.2,0.4$ \\
\hline India & 1980 & $-4.451^{* * *}$ & 0 & 0.20 & 1971 & 1994 & $-6.049^{* *}$ & 0 & $0.2,0.4$ \\
\hline Japan & 1974 & -3.980 & 1 & 0.10 & 1978 & 1986 & $-10.427^{*}$ & 8 & $0.2,0.4$ \\
\hline Malaysia & 1994 & $-9.230^{*}$ & 0 & 0.30 & 1990 & 1994 & $-10.503^{*}$ & 0 & $0.2,0.4$ \\
\hline Netherlands & 1977 & -3.400 & 0 & 0.20 & 1983 & 2001 & $-7.142^{*}$ & 8 & $0.2,0.6$ \\
\hline Pakistan & 1974 & $-6.324^{*}$ & 0 & 0.10 & 1992 & 1994 & $-6.760^{*}$ & 0 & $0.2,0.4$ \\
\hline Saudi Arabia & 1976 & $-6.135^{*}$ & 1 & 0.20 & 1977 & 2006 & $-7.441^{*}$ & 1 & $0.2,0.4$ \\
\hline Singapore & 2002 & $-6.100^{*}$ & 1 & 0.50 & 1983 & 1995 & $-8.123^{*}$ & 1 & $0.2,0.4$ \\
\hline South Africa & 2003 & $-8.075^{*}$ & 0 & 0.50 & 1987 & 2002 & $-8.525^{*}$ & 0 & $0.2,0.6$ \\
\hline Spain & 1997 & -3.435 & 0 & 0.40 & 1973 & 1997 & $-7.917^{*}$ & 7 & $0.2,0.4$ \\
\hline Thailand & 1980 & $-5.638^{*}$ & 0 & 0.20 & 1989 & 1997 & $-6.438^{*}$ & 3 & $0.2,0.4$ \\
\hline UK & 1974 & $-5.437^{*}$ & 0 & 0.10 & 1977 & 1994 & $-6.040^{* *}$ & 1 & $0.2,0.4$ \\
\hline USA & 1982 & -3.581 & 0 & 0.20 & 1981 & 1994 & $-5.839^{* *}$ & 8 & $0.2,0.4$ \\
\hline \multicolumn{10}{|c|}{ Nigeria Bilateral Real Exchange Rates } \\
\hline Countries & $T B$ & $\alpha$ & $k$ & $\lambda$ & $\mid T B_{1}$ & $T B_{2}$ & $\alpha$ & $k$ & $\lambda$ \\
\hline Australia & 1998 & $-5.291 *$ & 1 & 0.40 & 1986 & 1998 & $-7.354^{*}$ & 1 & $0.2,0.4$ \\
\hline Canada & 1997 & $-5.114^{*}$ & 2 & 0.40 & 1997 & 2003 & $-5.702^{* *}$ & 2 & $0.4,0.6$ \\
\hline China & 1984 & $-7.152^{*}$ & 0 & 0.30 & 1971 & 1979 & $-7.711^{*}$ & 4 & $0.2,0.4$ \\
\hline Cote D'Ivoire & 1977 & $-4.776^{* *}$ & 7 & 0.20 & 1977 & 1999 & $-5.524 * * *$ & 1 & $0.2,0.4$ \\
\hline Ghana & 1978 & $-5.035^{* *}$ & 1 & 0.20 & 1979 & 2006 & $-11.550^{*}$ & 1 & $0.2,0.4$ \\
\hline India & 1978 & $-6.857^{*}$ & 1 & 0.20 & 1975 & 1996 & $-7.386^{*}$ & 1 & $0.2,0.4$ \\
\hline Indonesia & 2000 & -3.931 & 1 & 0.40 & 1982 & 2004 & $-7.514^{*}$ & 3 & $0.2,0.4$ \\
\hline Japan & 1981 & $-5.651^{*}$ & 1 & 0.20 & 1981 & 1992 & $-19.594^{*}$ & 8 & $0.2,0.4$ \\
\hline South Africa & 1977 & $-6.270^{*}$ & 1 & 0.20 & 1977 & 1996 & $-6.757^{*}$ & 1 & $0.2,0.4$ \\
\hline South Korea & 1975 & -3.904 & 0 & 0.20 & 1982 & 2004 & $-7.754^{*}$ & 3 & $0.2,0.4$ \\
\hline Switzerland & 1975 & $-4.891^{* *}$ & 0 & 0.20 & 1989 & 1997 & $-7.929^{*}$ & 4 & $0.2,0.4$ \\
\hline Thailand & 1977 & $-4.261^{* * *}$ & 1 & 0.20 & 1971 & 1980 & $-5.775^{* *}$ & 1 & $0.2,0.4$ \\
\hline Turkey & 1981 & $-4.611^{* *}$ & 1 & 0.20 & 1981 & 2002 & $-5.799 * *$ & 8 & $0.2,0.4$ \\
\hline United Kingdom & 1987 & $-5.352^{*}$ & 3 & 0.30 & 1987 & 2001 & $-5.990 * *$ & 3 & $0.2,0.4$ \\
\hline USA & 1987 & $-5.197^{*}$ & 3 & 0.30 & 1981 & 1997 & $-6.660^{*}$ & 7 & $0.2,0.4$ \\
\hline
\end{tabular}




\begin{tabular}{|c|c|c|c|c|c|c|c|c|c|}
\hline \multicolumn{10}{|c|}{ Table 2c LM Tests } \\
\hline \multicolumn{10}{|c|}{ South Africa Bilateral Real Exchange Rates } \\
\hline Countries & $T B$ & $\alpha$ & $k$ & $\lambda$ & $T B_{1}$ & $T B_{2}$ & $\alpha$ & $k$ & $\lambda$ \\
\hline Botswana & 1999 & $-5.694^{*}$ & 0 & 0.40 & 1976 & 1998 & $-11.696^{*}$ & 8 & $0.2,0.4$ \\
\hline Canada & 1983 & $-4.750^{* *}$ & 0 & 0.30 & 1992 & 2004 & $-6.912^{*}$ & 2 & $0.4,0.6$ \\
\hline China & 1984 & $-6.636^{*}$ & 1 & 0.30 & 1971 & 1981 & $-7.918^{*}$ & 6 & $0.2,0.4$ \\
\hline France & 1997 & $-6.745^{*}$ & 8 & 0.40 & 1984 & 1997 & $-7.974^{*}$ & 8 & $0.2,0.4$ \\
\hline India & 1987 & $-6.102^{*}$ & 7 & 0.30 & 1994 & 2003 & $-7.665^{*}$ & 7 & $0.4,0.6$ \\
\hline Japan & 1984 & $-5.765^{*}$ & 1 & 0.30 & 1976 & 1988 & $-6.536^{*}$ & 0 & $0.2,0.4$ \\
\hline Kenya & 2004 & $-5.814^{*}$ & 0 & 0.50 & 1988 & 2002 & $-6.424^{*}$ & 0 & $0.2,0.6$ \\
\hline Netherlands & 1988 & -2.845 & 0 & 0.30 & 1984 & 2000 & -4.303 & 0 & $0.2,0.6$ \\
\hline Nigeria & 1977 & $-5.998 *$ & 1 & 0.20 & 1978 & 1997 & $-6.876^{*}$ & 1 & $0.2,0.4$ \\
\hline Switzerland & 1978 & $-4.827^{* *}$ & 0 & 0.20 & 1986 & 1997 & $-7.919^{*}$ & 8 & $0.2,0.4$ \\
\hline Thailand & 1988 & $-4.790 * *$ & 4 & 0.30 & 1973 & 1998 & $-6.634^{*}$ & 0 & $0.2,0.4$ \\
\hline Turkey & 1977 & $-4.417^{* * *}$ & 0 & 0.20 & 1981 & 1999 & $-5.921 * *$ & 0 & $0.2,0.4$ \\
\hline UK & 1985 & $-5.614^{*}$ & 3 & 0.30 & 1980 & 1999 & $-6.648^{*}$ & 4 & $0.2,0.4$ \\
\hline USA & 1985 & $-5.121^{* *}$ & 1 & 0.30 & 1982 & 1997 & $-5.879 * *$ & 1 & $0.2,0.4$ \\
\hline Zambia & 1993 & $-6.509^{*}$ & 0 & 0.30 & 1989 & 1995 & $-7.754^{*}$ & 0 & $0.2,0.4$ \\
\hline \multicolumn{10}{|c|}{ Tanzania Bilateral Real Exchange Rates } \\
\hline Countries & $T B$ & $\alpha$ & $k$ & $\lambda$ & $T B_{1}$ & $T B_{2}$ & $\alpha$ & $k$ & $\lambda$ \\
\hline Bahrain & 1996 & $-6.122^{*}$ & 7 & 0.30 & 1981 & 1996 & $-6.569^{*}$ & 7 & $0.20,0.40$ \\
\hline China & 1979 & $-4.871^{* *}$ & 0 & 0.10 & 1978 & 1991 & $-5.345 * * *$ & 8 & $0.20,0.40$ \\
\hline India & 1980 & $-5.390^{*}$ & 4 & 0.20 & 1980 & 1988 & $-7.961^{*}$ & 4 & $0.20,0.40$ \\
\hline Indonesia & 1984 & -2.420 & 3 & 0.20 & 1982 & 1998 & $-6.200^{*}$ & 0 & $0.20,0.40$ \\
\hline Japan & 1976 & $-4.310^{* * *}$ & 0 & 0.10 & 1971 & 1982 & $-7.417^{*}$ & 8 & $0.20,0.40$ \\
\hline Kenya & 1980 & -3.397 & 7 & 0.20 & 1985 & 1990 & -5.100 & 7 & $0.20,0.40$ \\
\hline South Korea & 1981 & -3.544 & 2 & 0.20 & 1979 & 1992 & $-6.702^{*}$ & 7 & $0.20,0.40$ \\
\hline Malaysia & 1982 & -3.728 & 0 & 0.20 & 1978 & 1990 & $-5.858^{* *}$ & 8 & $0.20,0.40$ \\
\hline Saudi Arabia & 1989 & $-4.408^{* * *}$ & 5 & 0.20 & 1978 & 1994 & $-6.535^{*}$ & 7 & $0.20,0.40$ \\
\hline Singapore & 1975 & $-4.311^{* * *}$ & 7 & 0.10 & 1979 & 1991 & $-6.720^{*}$ & 7 & $0.20,0.40$ \\
\hline South Africa & 1980 & -3.781 & 0 & 0.20 & 1979 & 1988 & $-5.889 * *$ & 3 & $0.20,0.40$ \\
\hline Switzerland & 1982 & $-4.449 * * *$ & 0 & 0.20 & 1981 & 1992 & $-9.279^{*}$ & 6 & $0.20,0.40$ \\
\hline Turkey & 1982 & -3.638 & 7 & 0.20 & 1976 & 1985 & $-7.567^{*}$ & 2 & $0.20,0.40$ \\
\hline UK & 1980 & $-4.372^{* * * *}$ & 2 & 0.20 & 1973 & 1989 & $-5.356^{* * *}$ & 6 & $0.20,0.40$ \\
\hline USA & 1979 & -3.499 & 0 & 0.10 & 1975 & 1992 & -4.901 & 8 & $0.20,0.40$ \\
\hline
\end{tabular}




\begin{tabular}{|c|c|c|c|c|c|c|c|}
\hline \multicolumn{8}{|c|}{ Table 3a: Tests for Symmetric Cointegration } \\
\hline \multicolumn{8}{|c|}{ Botswana } \\
\hline Country & $\beta_{0}$ & $\beta_{1}$ & $\beta_{2}$ & $\mathrm{ADF}$ & $\rho$ & $\mathrm{k}$ & $\mathrm{AIC}$ \\
\hline Belgium & 8.029 & -5.108 & 3.723 & -2.366 & -0.246 & 2 & 128.49 \\
\hline Canada & 1.644 & -1.054 & 1.049 & $-3.719^{* *}$ & -0.468 & 2 & -64.65 \\
\hline China & -0.130 & -0.436 & 0.399 & -1.575 & -0.123 & 1 & -28.55 \\
\hline France & 2.726 & -2.524 & 2.339 & -2.487 & -0.304 & 2 & 60.86 \\
\hline India & -0.985 & -1.139 & 0.927 & -2.931 & -0.224 & 1 & -56.51 \\
\hline Israel & 0.497 & -0.977 & 0.959 & -2.584 & -0.270 & 2 & -44.68 \\
\hline Japan & 7.226 & -0.647 & 0.468 & $-3.281^{* *}$ & -0.410 & 2 & -4.33 \\
\hline Norway & -1.506 & -0.617 & 0.931 & $-3.776^{* *}$ & -0.669 & 2 & -87.51 \\
\hline South Africa & 0.135 & -0.530 & 0.464 & $-3.254^{* * *}$ & -0.333 & 2 & -128.74 \\
\hline Switzerland & -1.917 & -0.207 & 0.981 & $-4.457^{*}$ & -0.577 & 1 & -60.31 \\
\hline Thailand & -2.427 & -0.623 & 0.767 & $-3.813^{* *}$ & -0.386 & 1 & -67.60 \\
\hline United Kingdom & -0.027 & -0.005 & 0.468 & -1.697 & -0.073 & 1 & -52.96 \\
\hline USA & 1.481 & -0.971 & 1.050 & -2.939 & -0.318 & 2 & -52.53 \\
\hline Zambia & -3.648 & -0.978 & 0.812 & -1.448 & -0.145 & 2 & 4.63 \\
\hline Zimbabwe & 2.460 & 1.882 & -2.027 & -1.353 & -0.047 & 1 & 132.98 \\
\hline \multicolumn{8}{|c|}{ Ghana } \\
\hline Country & $\beta_{0}$ & $\beta_{1}$ & $\beta_{2}$ & $\mathrm{ADF}$ & $\rho$ & $\mathrm{k}$ & $\mathrm{AIC}$ \\
\hline Algeria & -5.995 & -0.478 & 0.832 & -2.602 & -0.030 & 2 & 44.04 \\
\hline Canada & 12.309 & -4.363 & 1.638 & -2.827 & -0.190 & 1 & 57.18 \\
\hline China & -11.927 & 1.472 & 0.581 & -2.683 & -0.265 & 2 & 41.12 \\
\hline France & 16.656 & -5.740 & 2.102 & $-3.420^{* * *}$ & -0.359 & 2 & 93.42 \\
\hline India & -9.877 & 0.684 & 0.556 & -2.860 & -0.166 & 1 & 44.77 \\
\hline Japan & 0.391 & -2.408 & 1.317 & $-3.198^{* * *}$ & -0.199 & 1 & 53.31 \\
\hline Malaysia & 15.104 & -5.149 & 1.566 & -2.667 & -0.226 & 2 & 63.77 \\
\hline Nigeria & -5.915 & -0.469 & 0.712 & $-4.166^{*}$ & -0.507 & 1 & 69.82 \\
\hline Norway & 3.317 & -2.567 & 1.414 & -2.624 & -0.184 & 3 & 50.34 \\
\hline South Africa & -13.987 & 2.801 & -0.280 & -2.081 & -0.212 & 2 & 55.05 \\
\hline Singapore & 14.049 & -4.586 & 1.452 & -2.708 & -0.231 & 2 & 61.93 \\
\hline Switzerland & 4.196 & -2.279 & 1.281 & -2.421 & -0.160 & 2 & 57.20 \\
\hline Turkey & 0.023 & -0.493 & 0.419 & -2.526 & -0.218 & 2 & 52.95 \\
\hline United Kingdom & -4.230 & 0.042 & 0.886 & -2.133 & -0.094 & 1 & 50.34 \\
\hline USA & 16.771 & -5.471 & 1.819 & -2.881 & -0.248 & 2 & 64.50 \\
\hline
\end{tabular}




\begin{tabular}{|c|c|c|c|c|c|c|c|}
\hline \multicolumn{8}{|c|}{ Table 3b: Tests for Symmetric Cointegration } \\
\hline \multicolumn{8}{|c|}{ Kenya } \\
\hline Country & $\beta_{0}$ & $\beta_{1}$ & $\beta_{2}$ & $\mathrm{ADF}$ & $\rho$ & $\mathrm{k}$ & AIC \\
\hline China & 2.432 & -0.461 & 0.431 & -2.735 & -0.489 & 2 & -30.39 \\
\hline Egypt & 2.825 & 0.122 & -0.148 & $-3.585^{* *}$ & -0.435 & 2 & 4.14 \\
\hline France & 4.255 & -1.732 & 1.691 & -2.705 & -0.335 & 2 & 70.90 \\
\hline India & 1.326 & -0.825 & 0.652 & $-3.265^{* *}$ & -0.362 & 1 & -65.67 \\
\hline Japan & -3.823 & -0.149 & 0.192 & -2.046 & -0.157 & 1 & -14.19 \\
\hline Malaysia & 1.039 & -0.126 & 0.577 & -2.220 & -0.182 & 1 & -39.00 \\
\hline Netherlands & 2.445 & -0.710 & 1.112 & -2.421 & -0.314 & 2 & 5.24 \\
\hline Pakistan & 1.901 & -1.283 & 0.933 & $-3.239^{* * *}$ & -0.376 & 1 & -23.49 \\
\hline South Africa & 2.461 & -0.271 & 0.257 & -3.014 & -0.351 & 2 & -22.92 \\
\hline Saudi Arabia & 0.875 & -0.179 & 0.612 & -2.844 & -0.138 & 2 & -48.11 \\
\hline Singapore & 1.982 & -0.421 & 0.840 & -1.728 & -0.113 & 1 & -54.83 \\
\hline Spain & 0.691 & -2.725 & 3.282 & -2.665 & -0.281 & 2 & 167.14 \\
\hline Thailand & -0.059 & -0.494 & 0.674 & -2.034 & -0.172 & 1 & -39.54 \\
\hline United Kingdom & 2.383 & 0.074 & 0.427 & -1.746 & -0.074 & 1 & -54.46 \\
\hline USA & 3.232 & -0.577 & 0.811 & -1.446 & -0.102 & 1 & -50.42 \\
\hline \multicolumn{8}{|c|}{ Nigeria } \\
\hline Country & $\beta_{0}$ & $\beta_{1}$ & $\beta_{2}$ & $\mathrm{ADF}$ & $\rho$ & $\mathrm{k}$ & AIC \\
\hline Australia & 5.365 & -1.392 & 1.201 & -3.080 & -0.321 & 2 & 69.56 \\
\hline Canada & 6.486 & -1.628 & 1.213 & $-3.165^{* * *}$ & -0.291 & 2 & 1.46 \\
\hline China & -2.943 & -1.418 & 1.426 & $-3.199^{* * *}$ & -0.368 & 2 & 61.34 \\
\hline Cote D'Ivoire & -0.598 & -1.407 & 1.218 & $-3.285^{* * *}$ & -0.341 & 2 & 75.52 \\
\hline Ghana & 5.915 & -0.711 & 0.469 & $-4.166^{*}$ & -0.507 & 1 & 69.82 \\
\hline India & 2.998 & -1.663 & 1.224 & $-3.262^{* * *}$ & -0.290 & 1 & 69.65 \\
\hline Indonesia & 8.753 & -0.843 & 1.180 & -0.227 & -0.004 & 2 & 79.90 \\
\hline Japan & -0.379 & -1.063 & 1.197 & $-3.561^{* *}$ & -0.313 & 1 & 74.34 \\
\hline South Africa & 2.641 & -0.949 & 0.979 & -2.655 & -0.269 & 2 & 74.94 \\
\hline South Korea & -0.825 & -1.576 & 1.546 & -0.906 & -0.054 & 3 & 79.07 \\
\hline Switzerland & 4.754 & -1.228 & 1.199 & -3.093 & -0.325 & 2 & 70.62 \\
\hline Thailand & 3.796 & -1.803 & 1.253 & $-3.477^{* *}$ & -0.350 & 1 & 69.15 \\
\hline Turkey & 7.453 & -0.316 & -0.348 & -2.330 & -0.224 & 2 & 70.74 \\
\hline United Kingdom & 1.169 & 0.129 & 0.695 & -2.107 & -0.125 & 1 & 73.71 \\
\hline USA & 7.265 & -1.810 & 1.280 & $-3.302^{* * *}$ & -0.318 & 2 & 65.09 \\
\hline
\end{tabular}




\begin{tabular}{|c|c|c|c|c|c|c|c|}
\hline \multicolumn{8}{|c|}{ Table 3c: Tests for Symmetric Cointegration } \\
\hline \multicolumn{8}{|c|}{ South Africa } \\
\hline Country & $\beta_{0}$ & $\beta_{1}$ & $\beta_{2}$ & $\mathrm{ADF}$ & $\rho$ & $\mathrm{k}$ & AIC \\
\hline Botswana & -0.135 & -0.464 & 0.530 & $-3.254^{* * *}$ & -0.333 & 2 & -128.74 \\
\hline Canada & 1.911 & -1.245 & 1.195 & -3.107 & -0.400 & 2 & -45.08 \\
\hline China & -0.606 & -0.300 & 0.402 & -1.756 & -0.174 & 2 & -16.10 \\
\hline France & 2.695 & -2.657 & 2.425 & -2.188 & -0.194 & 2 & 69.96 \\
\hline India & -1.563 & -0.742 & 0.669 & -2.583 & -0.228 & 2 & -40.40 \\
\hline Japan & -5.663 & -0.529 & 1.171 & $-3.869^{* *}$ & -0.477 & 2 & -33.86 \\
\hline Kenya & -2.461 & -0.257 & 0.271 & -3.014 & -0.351 & 2 & -22.92 \\
\hline Netherlands & 0.083 & -0.997 & 1.373 & -1.964 & -0.154 & 2 & 7.53 \\
\hline Nigeria & -2.641 & -0.979 & 0.949 & -2.655 & -0.269 & 2 & 74.94 \\
\hline Switzerland & -1.677 & -0.344 & 1.078 & $-3.790^{* *}$ & -0.568 & 2 & -41.30 \\
\hline Thailand & -2.097 & -0.853 & 0.949 & $-4.938^{*}$ & -0.864 & 2 & -58.79 \\
\hline Turkey & 3.526 & -0.818 & 0.394 & -2.944 & -0.377 & 2 & -9.22 \\
\hline United Kingdom & -0.180 & 0.039 & 0.491 & -1.742 & -0.089 & 2 & -32.42 \\
\hline USA & 2.037 & -1.280 & 1.250 & -2.825 & -0.348 & 2 & -34.83 \\
\hline Zambia & -3.381 & -0.915 & 0.687 & -1.547 & -0.156 & 2 & 8.20 \\
\hline \multicolumn{8}{|c|}{ Tanzania } \\
\hline Country & $\beta_{0}$ & $\beta_{1}$ & $\beta_{2}$ & $\mathrm{ADF}$ & $\rho$ & $\mathrm{k}$ & $\mathrm{AIC}$ \\
\hline Bahrain & 7.462 & -0.977 & 1.098 & $-3.198^{* * *}$ & -0.282 & 2 & -30.76 \\
\hline China & -1.493 & 0.952 & 0.408 & -2.968 & -0.311 & 2 & -12.03 \\
\hline India & 4.389 & -1.463 & 1.182 & -2.097 & -0.157 & 2 & -11.86 \\
\hline Indonesia & -2.831 & -0.541 & 0.822 & -0.871 & -0.034 & 2 & 36.62 \\
\hline Japan & 2.500 & -1.295 & 1.275 & -3.093 & -0.250 & 2 & 0.96 \\
\hline Kenya & 1.001 & -0.392 & 0.737 & -2.969 & -0.196 & 2 & -9.20 \\
\hline Malaysia & 11.817 & -2.689 & 1.367 & $-3.243^{* * *}$ & -0.341 & 2 & -13.28 \\
\hline South Africa & 6.987 & -2.095 & 1.667 & -2.812 & -0.257 & 2 & 16.20 \\
\hline Saudi Arabia & 5.267 & -0.942 & 1.041 & $-3.597^{* *}$ & -0.271 & 2 & -33.94 \\
\hline Singapore & 11.238 & -2.332 & 1.329 & $-3.200^{* * *}$ & -0.277 & 2 & -16.39 \\
\hline South Korea & 1.002 & -1.585 & 1.364 & $-3.626^{* *}$ & -0.392 & 3 & -2.61 \\
\hline Switzerland & 9.125 & -1.846 & 1.337 & $-3.152^{* * *}$ & -0.263 & 2 & 1.565 \\
\hline Turkey & 7.367 & -0.767 & 0.605 & -3.084 & -0.204 & 2 & 11.24 \\
\hline United Kingdom & 2.629 & 0.368 & 0.646 & -2.501 & -0.176 & 2 & 30.45 \\
\hline USA & 11.599 & -2.511 & 1.503 & $-3.988^{* *}$ & -0.395 & 3 & -37.07 \\
\hline
\end{tabular}




\begin{tabular}{|c|c|c|c|c|c|c|c|c|}
\hline \multicolumn{9}{|c|}{ Table 4a: Tests for Asymmetric Cointegration } \\
\hline \multicolumn{9}{|c|}{ Botswana } \\
\hline Country & Model & $\tau$ & $\rho_{1}$ & $\rho_{2}$ & $\phi_{u}$ & $F_{\rho_{1}=\rho_{2}}$ & $\mathrm{AIC}$ & LB-Q \\
\hline Belgium & MTAR & -0.15 & -0.02 & -0.60 & $8.65^{* *}$ & $10.55^{*}$ & 117.73 & $4.08[0.39]$ \\
\hline Canada & MTAR & 0.02 & -0.79 & -0.28 & $11.23^{*}$ & $6.87^{*}$ & -68.20 & $0.59[0.96]$ \\
\hline China & MTAR & 0.10 & 0.30 & -0.22 & 5.66 & $8.44^{*}$ & -34.04 & $7.48[0.11]$ \\
\hline France & MTAR & -0.10 & -0.48 & 0.05 & 6.64 & $6.38^{*}$ & 55.27 & $1.31[0.85]$ \\
\hline India & MTAR & 0.05 & -0.41 & -0.14 & 6.11 & $3.24^{* *}$ & -56.66 & $2.76[0.59]$ \\
\hline Israel & TAR & -0.17 & -0.32 & -0.18 & 3.60 & 0.59 & -42.30 & $3.36[0.49]$ \\
\hline Japan & TAR & 0.18 & -0.62 & -0.20 & $7.87^{* *}$ & $4.22^{*}$ & -6.53 & $0.98[0.91]$ \\
\hline Norway & MTAR & 0.08 & -0.84 & -0.64 & $7.30^{* * *}$ & 0.49 & -84.18 & $1.20[0.88]$ \\
\hline South Africa & MTAR & 0.05 & -0.60 & -0.20 & $7.52^{* * *}$ & $3.81^{* *}$ & -128.03 & $1.20[0.88]$ \\
\hline Switzerland & MTAR & -0.06 & -0.48 & -1.10 & $12.91^{*}$ & $4.50^{*}$ & -61.63 & $0.86[0.92]$ \\
\hline Thailand & MTAR & 0.08 & -0.29 & 0.38 & $9.55^{* *}$ & $3.73^{* *}$ & -68.02 & $5.11[0.28]$ \\
\hline United Kingdom & MTAR & -0.01 & 0.02 & -0.17 & 4.39 & $5.63^{*}$ & -55.51 & $1.76[0.78]$ \\
\hline USA & MTAR & 0.07 & -0.60 & -0.16 & $7.74^{* * *}$ & $5.91^{*}$ & -55.41 & $0.78[0.94]$ \\
\hline Zambia & MTAR & 0.06 & -0.34 & -0.04 & 2.57 & $2.96^{* * *}$ & 3.54 & $0.40[0.98]$ \\
\hline Zimbabwe & MTAR & 0.05 & 0.01 & -0.15 & 3.64 & $5.29^{*}$ & 127.12 & $2.47[0.65]$ \\
\hline \multicolumn{9}{|c|}{ Ghana } \\
\hline Country & Model & $\tau$ & $\rho_{1}$ & $\rho_{2}$ & $\phi_{u}$ & $F_{\rho_{1}=\rho_{2}}$ & AIC & LB-Q \\
\hline Algeria & MTAR & -0.20 & -0.31 & 0.03 & 5.15 & $3.14^{b}$ & 41.77 & $2.14[0.71]$ \\
\hline Canada & MTAR & 0.10 & -0.37 & -0.11 & 6.08 & $3.71^{b}$ & 54.24 & $5.48[0.24]$ \\
\hline China & MTAR & 0.21 & -0.82 & -0.21 & $7.07^{* * *}$ & $6.06^{*}$ & 36.15 & $2.97[0.56]$ \\
\hline France & MTAR & -0.14 & -0.60 & 0.42 & $10.22^{* *}$ & $7.05^{*}$ & 86.37 & $0.64[0.96]$ \\
\hline India & MTAR & -0.25 & -0.27 & 0.09 & $9.73^{* *}$ & $9.66^{*}$ & 36.58 & $1.93[0.75]$ \\
\hline Japan & MTAR & 0.20 & -0.37 & -0.09 & $8.32^{* *}$ & $5.39^{*}$ & 49.80 & $4.21[0.38]$ \\
\hline Malaysia & MTAR & 0.05 & -0.34 & -0.13 & 4.51 & 1.77 & 62.62 & $4.73[0.32]$ \\
\hline Nigeria & TAR & -0.33 & -0.39 & -0.68 & $9.65^{* *}$ & 1.68 & 68.66 & $1.44[0.84]$ \\
\hline Norway & MTAR & 0.06 & -0.43 & -0.06 & $8.05^{* *}$ & $8.00^{*}$ & 43.19 & $8.98[0.06]$ \\
\hline South Africa & MTAR & -0.30 & -0.11 & -0.45 & 3.93 & $3.31^{* *}$ & 52.48 & $4.87[0.30]$ \\
\hline Singapore & TAR & -0.45 & -0.32 & -0.16 & 4.29 & 1.23 & 61.40 & $4.56[0.33]$ \\
\hline Switzerland & MTAR & 0.17 & -0.35 & -0.03 & 5.98 & $5.48^{*}$ & 52.43 & $9.68[0.04]$ \\
\hline Turkey & MTAR & 0.29 & -0.45 & -0.17 & 4.19 & 1.87 & 51.92 & $0.76[0.94]$ \\
\hline United Kingdom & MTAR & 0.18 & -0.31 & 0.01 & $8.43^{* *}$ & $11.27^{*}$ & 40.65 & $17.71[0.00]$ \\
\hline USA & MTAR & -0.10 & -0.06 & -0.55 & $10.76^{*}$ & $11.22^{*}$ & 54.34 & $5.20[0.27]$ \\
\hline $\begin{array}{l}*, * * \text { and } * * * \text { signify rej } \\
\phi_{u} \text { entries are the non-s } \\
\left(\rho_{1}=\rho_{2}=0\right) \text { for botl } \\
F_{\rho_{1}=\rho_{2}} \text { these are conve }\end{array}$ & $\begin{array}{l}\text { ctions at } \\
\text { andard F- } \\
\text { TAR and } \\
\text { tional F-s }\end{array}$ & $\begin{array}{l}\%, 5 \% \\
\text { stat dist } \\
\text { MTAR. }\end{array}$ & $\begin{array}{l}\text { nd } 10 \% \\
\text { ibution }\end{array}$ & of Eq. & $7 \& 8)$. & is test fo & ows a nol & $\begin{array}{l}\text { n-standard } \\
\text { Dibooglu }\end{array}$ \\
\hline
\end{tabular}




\begin{tabular}{|c|c|c|c|c|c|c|c|c|}
\hline \multicolumn{9}{|c|}{ Table 4b: Tests for Asymmetric Cointegration } \\
\hline \multicolumn{9}{|c|}{ Kenya } \\
\hline Country & Model & $\tau$ & $\rho_{1}$ & $\rho_{2}$ & $\phi_{u}$ & $F_{\rho_{1}=\rho_{2}}$ & AIC & LB-Q \\
\hline China & MTAR & 0.05 & -1.19 & -0.14 & $14.60^{*}$ & $18.81^{*}$ & -44.77 & $3.03[0.55]$ \\
\hline Egypt & MTAR & -0.05 & -0.28 & -0.78 & $10.52^{* *}$ & $6.61^{*}$ & -0.54 & $2.41[0.66]$ \\
\hline France & MTAR & -0.06 & -0.05 & -0.64 & $8.10^{* *}$ & $7.81^{*}$ & 63.76 & $4.19[0.38]$ \\
\hline India & MTAR & 0.03 & -0.79 & -0.12 & $12.90^{*}$ & $12.58^{*}$ & -74.16 & $4.01[0.40]$ \\
\hline Japan & MTAR & -0.13 & -0.19 & 0.03 & 2.99 & 2.24 & -15.79 & $0.52[0.97]$ \\
\hline Malaysia & TAR & -0.09 & -0.24 & -0.08 & 2.98 & 1.04 & -37.26 & $1.71[0.79]$ \\
\hline Netherlands & TAR & -0.19 & -0.11 & -0.68 & $6.99^{* * *}$ & $7.31^{*}$ & -0.12 & $3.04[0.55]$ \\
\hline Pakistan & MTAR & 0.02 & -0.63 & 0.02 & $11.82^{*}$ & $10.97^{*}$ & -31.44 & $0.91[0.92]$ \\
\hline South Africa & MTAR & 0.12 & -0.60 & -0.26 & 5.87 & 2.37 & -22.86 & $1.46[0.83]$ \\
\hline Saudi Arabia & TAR & 0.14 & -0.11 & -0.33 & 4.45 & 2.34 & -45.94 & $1.65[0.80]$ \\
\hline Singapore & TAR & 0.10 & -0.16 & -0.06 & 1.77 & 0.57 & -52.30 & $2.79[0.59]$ \\
\hline Spain & MTAR & -0.28 & -0.43 & 0.10 & $7.69^{* * *}$ & $7.32^{*}$ & 158.53 & $6.69[0.15]$ \\
\hline Thailand & MTAR & 0.03 & -0.44 & -0.01 & 5.79 & $6.93^{*}$ & -43.57 & $5.26[0.26]$ \\
\hline United Kingdom & TAR & 0.22 & -0.16 & -0.03 & 2.63 & 2.14 & -53.54 & $3.24[0.52]$ \\
\hline USA & MTAR & 0.05 & -0.45 & -0.01 & 5.00 & $7.62^{*}$ & -54.86 & $1.88[0.76]$ \\
\hline \multicolumn{9}{|c|}{ Nigeria } \\
\hline Country & Model & $\tau$ & $\rho_{1}$ & $\rho_{2}$ & $\phi_{u}$ & $F_{\rho_{1}=\rho_{2}}$ & AIC & LB-Q \\
\hline Australia & MTAR & -0.19 & -0.17 & -0.83 & $11.90^{*}$ & $12.02^{*}$ & 58.69 & $2.86[0.58]$ \\
\hline Canada & MTAR & -0.12 & -0.18 & -0.62 & $8.98^{* *}$ & $6.71^{*}$ & 61.21 & $2.23[0.69]$ \\
\hline China & TAR & -0.45 & -0.23 & -0.62 & $7.34^{* * *}$ & $3.82^{* *}$ & 58.25 & $2.28[0.68]$ \\
\hline Cote D'Ivoire & MTAR & -0.06 & -0.57 & -0.05 & $11.57^{*}$ & $10.19^{*}$ & 66.12 & $0.76[0.94]$ \\
\hline Ghana & TAR & 0.38 & -0.68 & -0.39 & $9.64^{* *}$ & 1.68 & 68.66 & $1.43[0.84]$ \\
\hline India & MTAR & 0.07 & -0.76 & -0.19 & $10.19^{* *}$ & $8.15^{*}$ & 62.37 & $1.28[0.87]$ \\
\hline Indonesia & MTAR & 0.11 & -0.82 & -0.14 & $24.90^{*}$ & $31.56^{*}$ & 37.46 & $1.15[0.89]$ \\
\hline Japan & MTAR & -0.18 & -0.21 & -0.73 & $10.32^{* *}$ & $6.51^{*}$ & 68.48 & $1.91[0.75]$ \\
\hline South Africa & MTAR & -0.11 & -0.09 & -0.52 & $6.98^{* * *}$ & $6.14^{*}$ & 69.30 & $1.43[0.84]$ \\
\hline South Korea & MTAR & -0.25 & -0.21 & -1.02 & $17.08^{*}$ & $18.88^{*}$ & 47.23 & $3.66[0.45]$ \\
\hline Switzerland & MTAR & -0.15 & -0.51 & -0.04 & $9.26^{* *}$ & $7.58^{*}$ & 63.69 & $1.14[0.89]$ \\
\hline Thailand & MTAR & -0.22 & -0.17 & -0.76 & $11.49^{*}$ & $8.91^{*}$ & 61.19 & $0.98[0.91]$ \\
\hline Turkey & MTAR & -0.25 & -0.17 & -0.60 & 4.45 & $3.22^{* *}$ & 68.06 & $4.39[0.35]$ \\
\hline United Kingdom & MTAR & 0.04 & -0.44 & -0.04 & $7.57^{* * *}$ & $9.88^{*}$ & 64.80 & $0.83[0.93]$ \\
\hline USA & MTAR & -0.08 & -0.21 & -0.53 & $7.51^{* * *}$ & $3.52^{* *}$ & 62.22 & $0.89[0.93]$ \\
\hline
\end{tabular}




\begin{tabular}{|c|c|c|c|c|c|c|c|c|}
\hline \multicolumn{9}{|c|}{ Table 4c: Tests for Asymmetric Cointegration } \\
\hline \multicolumn{9}{|c|}{ South Africa } \\
\hline Country & Model & $\tau$ & $\rho_{1}$ & $\rho_{2}$ & $\phi_{u}$ & $F_{\rho_{1}=\rho_{2}}$ & AIC & LB-Q \\
\hline Botswana & MTAR & -0.05 & -0.20 & -0.60 & $7.52^{* * *}$ & $3.81^{* *}$ & -128.03 & $1.20[0.88]$ \\
\hline Canada & TAR & 0.15 & -0.78 & -0.21 & $9.59^{* *}$ & $8.04^{*}$ & -50.12 & $0.76[0.94]$ \\
\hline China & MTAR & 0.10 & -0.35 & -0.11 & 2.35 & 1.57 & -15.34 & $1.74[0.78]$ \\
\hline France & MTAR & 0.03 & -0.55 & 0.01 & $10.07^{* *}$ & $14.00^{*}$ & 57.40 & $8.41[0.07]$ \\
\hline India & TAR & 0.21 & -0.61 & -0.08 & $9.99^{* *}$ & $11.75^{*}$ & -48.84 & $1.97[0.74]$ \\
\hline Japan & MTAR & 0.06 & -0.70 & -0.31 & $10.11^{* *}$ & $4.20^{* *}$ & -35.43 & $1.59[0.81]$ \\
\hline Kenya & TAR & 0.16 & -0.52 & -0.29 & 5.19 & 1.25 & -21.69 & $0.74[0.95]$ \\
\hline Netherlands & MTAR & 0.09 & -0.61 & -0.03 & $9.37^{* *}$ & $13.81^{*}$ & -3.61 & $7.00[0.13]$ \\
\hline Nigeria & MTAR & 0.13 & -0.52 & -0.10 & $6.98^{* * *}$ & $6.14^{*}$ & 69.29 & $1.43[0.84]$ \\
\hline Switzerland & TAR & 0.11 & -0.69 & -0.46 & $7.72^{* *}$ & 1.06 & -39.50 & $2.06[0.72]$ \\
\hline Thailand & MTAR & 0.09 & -1.08 & -0.64 & $14.58^{*}$ & $3.48^{* *}$ & -59.14 & $3.63[0.46]$ \\
\hline Turkey & TAR & -0.15 & -0.28 & -0.57 & 5.14 & 1.51 & -8.53 & $4.05[0.40]$ \\
\hline United Kingdom & MTAR & 0.07 & -0.31 & -0.03 & 4.60 & $5.84^{*}$ & -35.63 & $2.12[0.71]$ \\
\hline USA & MTAR & 0.11 & -0.43 & -0.26 & 4.32 & 0.71 & -32.78 & $1.23[0.87]$ \\
\hline Zambia & MTAR & 0.01 & -0.43 & 0.03 & 5.46 & $8.16^{*}$ & 1.99 & $0.42[0.98]$ \\
\hline \multicolumn{9}{|c|}{ Tanzania } \\
\hline Country & Model & $\tau$ & $\rho_{1}$ & $\rho_{2}$ & $\phi_{u}$ & $F_{\rho_{1}=\rho_{2}}$ & AIC & LB-Q \\
\hline Bahrain & MTAR & -0.02 & -0.14 & -0.41 & $7.09^{* * *}$ & $3.35^{* *}$ & -31.48 & $2.64[0.62]$ \\
\hline China & TAR & -0.25 & -0.27 & -0.36 & 4.45 & 0.26 & -9.91 & $2.43[0.66]$ \\
\hline India & MTAR & -0.16 & -0.05 & -0.46 & 5.99 & $6.95^{*}$ & -16.51 & $2.02[0.73]$ \\
\hline Indonesia & MTAR & -0.14 & -0.03 & 0.44 & 4.22 & $5.25^{*}$ & 30.31 & $2.06[0.73]$ \\
\hline Japan & MTAR & -0.10 & -0.05 & -0.62 & $17.61^{*}$ & $20.99^{*}$ & -15.48 & $2.91[0.57]$ \\
\hline Kenya & MTAR & 0.10 & -0.60 & -0.15 & $7.71^{* * *}$ & $5.60^{*}$ & -12.62 & $1.15[0.89]$ \\
\hline Malaysia & TAR & -0.27 & -0.21 & -0.56 & $7.47^{* * *}$ & $3.72^{* *}$ & -14.76 & $3.81[0.43]$ \\
\hline South Africa & TAR & -0.39 & -0.07 & -0.41 & $6.60^{* * *}$ & $4.59^{*}$ & 13.18 & $5.62[0.22]$ \\
\hline Saudi Arabia & MTAR & -0.12 & -0.19 & -0.47 & $8.76^{* *}$ & $3.71^{* *}$ & 34.96 & $9.83[0.04]$ \\
\hline Singapore & MTAR & 0.03 & -0.47 & -0.18 & $7.30^{* * *}$ & $3.69^{* *}$ & -17.78 & $2.63[0.62]$ \\
\hline South Korea & TAR & -0.60 & -0.04 & -0.34 & 4.95 & $5.07^{*}$ & 4.74 & $1.99[0.74]$ \\
\hline Switzerland & MTAR & -0.15 & -0.12 & -0.73 & $16.34^{*}$ & $18.53^{*}$ & -13.09 & $7.40[0.12]$ \\
\hline Turkey & MTAR & -0.01 & -0.41 & -0.11 & $7.89^{* * *}$ & $5.28^{*}$ & 7.65 & $5.56[0.23]$ \\
\hline United Kingdom & MTAR & 0.13 & -0.75 & -0.14 & 6.23 & $5.52^{*}$ & 26.21 & $4.41[0.35]$ \\
\hline USA & TAR & 0.23 & -0.27 & -0.49 & $9.40^{* *}$ & 2.35 & -36.63 & $5.11[0.28]$ \\
\hline
\end{tabular}

